\title{
Determinante stranih direktnih investicija u tranzicijskim zemljama i procjena njihove potencijalne razine u Hrvatskoj
}

Derado, Dražen

Source / Izvornik: Odabrani prijevodi, 2013, 4, 1 - 29

Journal article, Published version

Rad u časopisu, Objavljena verzija rada (izdavačev PDF)

https://doi.org/10.3326/op.17

Permanent link / Trajna poveznica: https://urn.nsk.hr/urn:nbn:hr:242:326514

Rights / Prava: Attribution-NonCommercial-NoDerivatives 4.0 International/ImenovanjeNekomercijalno-Bez prerada 4.0 međunarodna

Download date / Datum preuzimanja: 2023-04-26

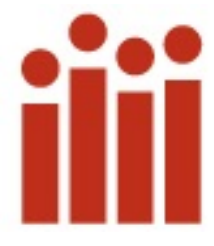

Repository / Repozitorij:

Institute of Public Finance Repository

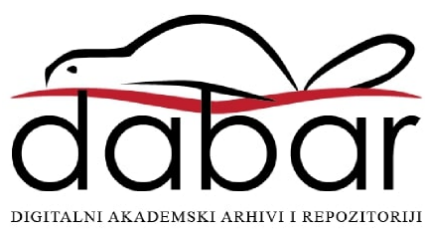


Institut za

javne financije

Smičiklasova 2I | Zagreb

www.ijf.hr | ured@ijf.hr

T: oI/4886-444 | F: OI/4819-365

\section{DETERMINANTE STRANIH DIREKTNIH INVESTICIJA}

\section{U TRANZICIJSKIM ZEMLJAMA I PROGJENA NJIHOVE}

\section{POTENCIJALNE RAZINE U HRVATSKOJ}

\author{
IZVORNI ZNANSTVENI RAD \\ JEL: F2I, F23 \\ DOI: $10.3326 /$ op.17
}

\section{OdABRANI \\ PRIJEVODI}

ISSN I $847-7445$

\section{BR. I7/I3}

\section{SAŽETAK}

U globalnoj ekonomiji strane direktne investicije (FDI) predstavljaju najznačajniji oblik međunarodnih poslovnih aktivnosti. One ne predstavljaju samo prekogranično kretanje kapitala, već uključuju i transfer tehnologije i znanja, te na taj način doprinose rastu konkurentnosti, zaposlenosti i međunarodnoj trgovini, a kao posljedica toga, i ekonomskom rastu i razvoju lokalnog gospodarstva. Nedavni pad globalnih tijekova kapitala, kao posljedica svjetske financijske i ekonomske krize, izazvao je zabrinutost po pitanju očekivanog rasta svjetskog gospodarstva u cjelini, a posebno manje naprednih tranzicijskih zemalja. Polazeći od konstatacije da je Hrvatska, kao sljedeća članica EU-a, ostvarila suboptimalne efekte u privlačenju FDI, te da će međunarodna konkurencija na tom planu prema očekivanjima rasti i u budućnosti, cilj rada je utvrditi determinante priljeva FDI $u$ tranzicijske zemlje u sorhu utvrđivanja preostalih kapaciteta Hrvatske u njihovu prihvaćanju. Statistička analiza, temeljena na bilateralnim tijekovima FDI $i$ specifičnim obilježjima zemalja, potvrdila je važnost tipičnih "gravitacijskih" varijabli, ali i varijabli rastućih prinosa na obujam, kao determinanti FDI, te je dokazala da je Hrvatska zasad uglavnom iskoristila postojeće kapacitete u privlačenju FDI.

Ključne riječi: FDI, gravitacijska jednadžba, ekonomija obujma, tranzicijske zemlje, Hrvatska

" Ovaj rad nastao je u okviru istraživačkog projekta br. 055-055I207-0776, koje je financiralo Ministarstvo znanosti, obrazovanja i sporta Republike Hrvatske. Autor zahvaljuje trima anonimnim recenzentima na korisnim komentarima i prijedlozima.

"** Primljeno: 2O. prosinca 2012.

Prihvaćeno: 26. siječnja 2013.

Dražen DERADO

Sveučilište u Splitu, Ekonomski fakultet, Cvite Fiskovića 5, 2100o Split, Hrvatska

e-mail: dderado@efst.hr 


\section{UVOD}

U globalnoj ekonomiji u kojoj danas dominiraju multinacionalna poduzeća (MNP), inozemna ulaganja predstavljaju najznačajniji oblik međunarodnih poslovnih aktivnosti. Kao način financiranja gospodarskog rasta koji ne stvara dug u klasičnom smislu riječi, FDI donose kapital, tehnologiju i znanje, doprinoseći na taj način rastu produktivnosti i ukupnom razvoju lokalnog gospodarstva. Rast konkurentnosti koji iz toga proizlazi, doprinosi rastućoj internacionalizaciji poslovanja i lakšem pristupu međunarodnim tržištima.

Ipak, globalna financijska kriza (2008/og.) značajno je smanjila međunarodne tijekove kapitala i skoro prepolovila ukupne svjetske FDI, pri čemu je najveći pad ostvaren u razvijenim zemljama, uključujući i EU (za 40-60\%), a nakon čega je uslijedio tek blagi oporavak i rast od I6\% u 2OII. Najveća opasnost za daljnji pozitivni razvoj događaja dolazi iz još uvijek nestabilnog poslovnog okruženja i problema makroekonomskog upravljanja $\mathrm{u}$ uvjetima dužničke krize i problema $\mathrm{u}$ financijskom sektoru (eurozoni). Pa ipak, zahtjevi za daljnjom internacionalizacijom poslovanja prisiljavaju MNP-e na poslovno restrukturiranje, što im je u proteklom razdoblju i pomoglo da unaprijede poslovne performanse i pritom generiraju nova ulaganja na globalnoj razini (UNCTAD, 2OI2; 2OII).

Različiti motivi za FDI zahtijevaju specifične lokacijske prednosti zemlje primateljice (Dunning, 1993; 1997). Traženje resursa (resource-seeking FDI) zahtijeva dostupnost korisnih resursa kojima se može opravdati premještanje proizvodnje $\mathrm{u}$ drugu zemlju. FDI koje primarno imaju ovaj motiv, danas ostvaruju rast u vrijednosti ulaganja i broju projekata, budući su uglavnom usredotočene na preradu nafte, te poljoprivredu i industriju hrane (UNCTAD, 20Io). Traženje tržišta (market-seeking FDI), kao motiv za FDI, primarno je usmjereno na ostvarivanje stabilnih i rastućih tržišnih udjela i to ulaženjem na nova tržišta, ponekad i s ciljem izbjegavanja postojećih trgovinskih barijera (više u: Bergstrand i Egger, 2007; Clausing i Dorobantu, 2005; Girma, Greenaway i Wackelin, 2002). Ulaganja s ovim motivom usredotočena su na opskrbljivanje lokalnog i/ili susjednih tržišta, povezivanje s dobavljačima i tržištem potrošača, odnosno prilagođavanje roba i usluga lokalnim ukusima i preferencijama potrošača (Leffileur i Maurel, 20Io; Borrmann, Jungnickel i Keller, 2005). Najvažnija lokacijska prednost za ovaj tip FDI jest veliko domaće tržište sa snažnim potencijalima rasta i povoljnom ulagačkom klimom.

Najvažniji cilj inozemnih ulaganja motiviranih traženjem efikasnosti (effciency-seeking FDI) predstavlja težnja za unaprjeđenjem efikasnosti u proizvodnji putem diferencijacije i geografske separacije faza proizvodnje, odnosno poslovnih aktivnosti, a u skladu s komparativnim prednostima zemlje domaćina. Stvaranje jednog ovakvog lanca dodane vrijednost omogućava velikom broju poduzeća iz različitih zemalja sudjelovanje $\mathrm{u}$ internacionalizaciji poslovanja i dolaženju u kontakt $\mathrm{s}$ novim tehnologijama $\mathrm{i}$ znanjima. To također daje priliku manje naprednim (tranzicijskim) zemljama za sudjelovanje u međunarodnoj proizvodnji i ostvarivanje konkurentnosti u užim tržišnim nišama, uz uvjet provođenja politike otvorenog tržišta i razvijanja apsorpcijskih kapaciteta u terminima ljudskog kapitala i stvaranja 
i prihvaćanja novih znanja ${ }^{\mathrm{I}}$. K tome, uvjeti lokalnog tržišta redovito trebaju uključivati i ljudski kapital kao najznačajniji faktor privlačenja FDI u dugom roku (Wang i Swain, 1995; Barell i Paine, 1999). Tehnološki napredak, internalizacija vlasničkih prednosti multinacionalnih poduzeća, kao i deregulacija tržišta, stavljaju danas sve veći naglasak na stvaranje znanja, zbog čega su zemlje s niskim nadnicama osuđene na privlačenje radno-intenzivne proizvodnje standardne tehnologije i stagnirajuće tržišne potražnje. Konačno, FDI motivirane strateškim razlozima (strategic asset-seeking FDI) imaju za cilj povećanje i diverzifikaciju imovine MNP-a, što također uključuje i strateško pozicioniranje na monopolskim, odnosno oligopolskim tržištima. Poduzeća s ovim motivom obično imaju dulji vremenski horizont ulaganja, te se uključuju u velike privatizacijske projekte (npr. u istočnoj Europi tijekom I990-ih godina).

Značajan priljev FDI, koji je Hrvatska ostvarila tijekom I990-ih godina i prvog desetljeća novog milenija, nije ostvario značajniji pozitivni utjecaj na domaće gospodarstvo (Derado, Škudar i Rakušić, 2OII; Vukšić, 2005; Bačić, Račić i Ahec Šonje, 2004). S obzirom na aktualne ekonomske probleme na globalnoj razini, koji su se odrazili na iznos i strukturu svjetskih FDI, kao i na spori oporavak poslovne klime u jugoistočnoj Europi (JIE), realno je za očekivati nastavak sporog rasta priljeva FDI u Hrvatsku i ostale zemlje JIE i u budućnosti. Polazeći od konstatacije da je Hrvatska ostvarila suboptimalne efekte u privlačenju FDI, te da će konkurencija na tom planu nastaviti jačati i u budućnosti (istočna Azija, nove zemlje članice EU-a), cilj rada je utvrditi faktore koji određuju ukupni priljev FDI u tranzicijske zemlje, a u svrhu određivanja kapaciteta Hrvatske za prihvaćanje novih FDI. Stoga, analiza će ukazati na najvažnije determinante FDI, te će empirijski verificirati teorijske hipoteze na kojima počiva.

Relevantnost ovoga istraživanja proizlazi iz činjenice da model gospodarskog rasta, utemeljen na rastućoj domaćoj potražnji financiranoj inozemnim zaduživanjem, nije više moguć zbog sve teže održivih eksternih pozicija zemalja, kao i financijskih problema kod najznačajnijih ulagača u inozemstvo. Kompleksnost teorijske i empirijske analize u ovome radu proizlazi iz kombinacije dvaju modela - gravitacijske jednadžbe i rastućih prinosa na obujam - $u$ objašnjavanju dolaznih FDI $u$ tranzicijske zemlje. Analiza na nižoj razini agregiranja podataka (bilateralni tijekovi FDI za parove zemalja), dulje vremenske serije i velika skupina tranzicijskih zemalja kao referenca za zemlje JIE, te utvrđivanje potencijalne, odnosno “teorijski očekivane” razine FDI, predstavljaju najznačajnija obilježja ovoga analitičkog pristupa, koji prema autorovim spoznajama, po prvi put uključuje i Hrvatsku. Relevantnost ovoga rada s ekonomsko-političkog stajališta leži u doprinosu boljem razumijevanju faktora koji determiniraju bilateralne FDI, kao i granice njihova mogućeg rasta u budućnosti.

Rad se sastoji od pet dijelova. Nakon uvodnog dijela, u drugom dijelu prezentirana je teorijska podloga za analizu FDI, bazirana na konceptima relativne raspoloživosti proizvodnih faktora, rastućih prinosa na obujam i prekograničnih poslovnih operacija MNP-a. U trećem dijelu dan je pregled trendova visine i strukture FDI u Hrvatskoj i ostalim tranzicijskim zemljama JIE. Empirijska analiza najznačajnijih

\footnotetext{
${ }^{\mathrm{I}}$ Institucionalni uvjeti igraju važnu ulogu u realizaciji transfera tehnologije i unaprjeđenju apsorpcijskih kapaciteta lokalne ekonomije (više u: Barrios i Strobl, 2002; Braunerhjelm i Svensson, 1996; Te Velde, 200I).
} 
determinanti i očekivane razine FDI u Hrvatskoj prikazana je $u$ četvrtom dijelu rada. Posljednji dio sadrži zaključke.

\section{TEORIJSKA POLAZIŠTA ZA ANALIZU FDI}

\section{I. OD TEORIJE TRGOVINE DO VERTIKALNIH FDI: HELPMAN I KRUGMAN}

Rani radovi objašnjavali su međunarodne tijekove kapitala (primarno financijska ulaganja) kao arbitražu kamatnih stopa, dok su ih kasniji doprinosi, utemeljeni na neoklasičnoj paradigmi, tumačili kao posljedicu postojanja razlika u graničnim prinosima između zemalja (Frenkel, Funke i Stadtmann, 2004; Hosseini, 2005). Ipak, prvi značajniji doprinos razumijevanju FDI kao posljedice prekograničnih poslovnih aktivnosti MNP-a ponudio je Helpman (1984). Njegov analitički model s radom i upravljačkim uslugama (headquarters services) kao najznačajnijim proizvodnim faktorima uključivao je dva proizvoda: homogeni (radno-intenzivni) proizvod, proizveden uz konstantne prinose na obujam, i diferencirani proizvod, intenzivan upravljačkim uslugama i proizveden uz rastuće prinose na obujam. Uz pretpostavku postojanja razlika u relativnoj raspoloživosti proizvodnih faktora po zemljama, i uz odsustvo trgovinskih barijera, uzorak trgovine $\mathrm{u}$ ovome je modelu određen razlikama $\mathrm{u}$ relativnoj faktorskoj raspoloživosti i relativnoj veličini zemlje. Daljnja unaprjeđenja ovoga pristupa mogu se pronaći kod Helpmana i Krugmana (1986) gdje se spoznaje nove teorije trgovine neposredno primjenjuju na primjeru MNP-a. Osim intra- i inter-industrijske trgovine, i uz standardne modelske pretpostavke i razlike u relativnoj faktorskoj raspoloživosti, ovaj model uvodi trgovinu unutar poduzeća (intra-firm trade) znanjem-intenzivnim upravljačkim uslugama ${ }^{2}$ (knowledge-intensive headquarters services). Kombinirajući princip faktorskih proporcija s diferencijacijom proizvoda i ekonomijom obujma, ovaj model objašnjava FDI kao oblik vertikalnog poslovnog povezivanja koje je posljedica razlika u relativnim faktorskim proporcijama između zemalja ${ }^{3}$.

\subsection{IZBOR IZMEĐU BLIZINE I KONCENTRAGIJE I HORIZONTALNIH FDI: DOPRINOS LAEL BRAINARD}

Za razliku od standardnog pristupa faktorskih proporcija, Lael Brainard pretpostavlja identične faktorske proporcije između zemalja, što zahvaljujući poslovnim aktivnostima MNP-a rezultira u horizontalnim FDI. U ovom slučaju pretpostavlja se postojanje dvaju sektora - jednoga s homogenim proizvodima uz konstantne prinose na obujam, i drugoga s diferenciranim proizvodima i rastućim prinosima na obujam na nivou poduzeća. Osim identičnih potrošačkih preferencija u zemljama, ovaj model pretpostavlja i postojanje ekonomije obujma na nivou proizvodnog pogona, postojanje trgovinskih barijera i transportnih troškova, kao i monopolističku konkurenciju Chamberlinovog tipa u sektoru diferenciranih proizvoda (Brainard, 1993). Zbog prisutnosti transportnih i transakcijskih troškova s jedne strane i ekonomije obujma, s druge strane, kao glavni razlog lociranja podružnice

\footnotetext{
${ }^{2}$ Pretpostavke modela uključuju: dva proizvodna faktora, dva finalna proizvoda (homogeni - hrana; diferencirani - industrijski proizvod) i jedan intermedijarni proizvod (upravljačke usluge), odsustvo transportnih i transakcijskih troškova, nepostojanje trgovinskih barijera i nepostojanje razlika u poreznim sustavima (Helpman i Krugman, 1986).

${ }^{3}$ Helpman (2006) je unaprijedio ovu analizu uvodeći pretpostavku o heterogenosti unutar industrije s obzirom na razlike u nivou produktivnosti, kao i različite organizacijske oblike između poduzeća unutar iste industrije.
} 
MNP-a treba tražiti u izboru između dodatnog troška izvoza i troška pokretanja proizvodnje u inozemstvu (proximity-concentration trade off). Ako varijabilni trošak izvoza premašuje trošak pokretanja posla u inozemstvu (bliže ciljanom tržištu), tada će se pojaviti horizontalne FDI.

Opisani model može rezultirati u tri tipa tržišne ravnoteže - tzv. čista multinacionalna, čista trgovinska i miješana ravnoteža. U čistoj multinacionalnoj ravnoteži, zbog visokih troškova trgovanja i transporta, i relativno niskog fiksnog troška izgradnje proizvodnih kapaciteta $u$ inozemstvu, multinacionalna proizvodnja će dominirati i u cijelosti zamijeniti trgovinu finalnim proizvodima, uz jedinu iznimku trgovine nevidljivim upravljačkim uslugama (za detalje vidjeti: Brainard, 1997).

\subsection{MARKUSENOVO OBJEDINJAVANJE HORIZONTALNIH I VERTIKALNIH FDI}

Markusen se na temelju pristupa industrijske organizacije bavio aktivnostima multinacionalnih poduzeća u okviru trgovinskog modela opće ravnoteže i ponudio objašnjenje horizontalnih i vertikalnih aktivnosti MNP-a. Njegov model kapitala i znanja (knowledge-capital model) sastoji se od dvije zemlje, dva homogena proizvoda i dva proizvodna faktora (kvalificirani i nekvalificirani rad). Proizvod intenzivan nekvalificiranim radom nastaje uz konstantne prinose i u uvjetima savršene konkurencije, dok se proizvod intenzivan kvalificiranim radom stvara uz rastuće prinose na obujam i u uvjetima monopolističke konkurencije, ili oligopola Cournotovog tipa. Proizvod intenzivan kvalificiranim radom koristi i upravljačke usluge (heaadquarters services), (Markusen i Maskus, 1999). Nadalje, u modelu se pretpostavlja mogućnost geografskog diferenciranja poslovnih aktivnosti tako da svaka firma ima proizvodni pogon u inozemstvu. Model, nadalje predviđa postojanje transportnih troškova i segmentirana nacionalna tržišta, kao i nemobilnost proizvodnih faktora između zemalja (Markusen i Maskus, 2002; Carr, Markusen i Maskus, 1998).

U modelu se pretpostavlja postojanje ekonomije obujma na nivou poduzeća u cjelini, ali i pojedinih proizvodnih pogona, kao i mogućnost prostornog razdvajanja usluga upravljanja i aktivnosti neposredno vezanih uz proizvodnju, prema njihovoj faktorskoj intenzivnosti i relativnoj raspoloživosti proizvodnih faktora po zemljama. Ako su fiksni troškovi na nivou poduzeća dovoljno visoki da učine ekonomiju obujma na nivou poduzeća važnijom od one na nivou pojedine proizvodnje, tada će se pojaviti MNP kroz proizvodnju koju realiziraju podružnice u inozemstvu, i ponudu usluga upravljanja koja dolazi iz zemlje porijekla MNP-a (Carr i dr., 1998). Usluge upravljanja intenzivne kvalificiranim radom, koje zauzimaju središnje mjesto u konkretnom modelu, mogu se bez većih problema odvojiti od proizvodnje, transferirati u dislociranu proizvodnju i dijeliti između različitih proizvodnih kapaciteta (Markusen, 2002). Vertikalni ili horizontalni MNP-i potiču, putem karaktera tipa svojih prekograničnih poslovnih aktivnosti, vertikalne ili horizontalne FDI. Pritom, vertikalne FDI nastupaju kao posljedica zemljopisnog razdvajanja poslovnih aktivnosti, prema fazama poslovnog procesa, dok horizontalne FDI predviđaju ekspanziju iste proizvodnje između različitih zemalja. Simultano objašnjenje obaju tipova FDI, kao najveća prednost ovoga modela, moguće je zahvaljujući simultanom uključivanju troškova trgovine i razlika u faktorskoj intenzivnosti u isti analitički model. 
Obilježja zemlje i industrije imaju značajni utjecaj na aktivnosti MNP-a, a time i na tip FDI. Horizontalne FDI pojavljuju se kad postoje sličnosti u veličini tržišta i relativnoj raspoloživosti proizvodnih faktora (troškovi proizvodnih faktora) između zemlje porijekla i zemlje odredišta FDI, te kad postoje visoki transportni troškovi (Markusen i Venables, 1998). Vertikalne FDI javljaju se kod zemalja različitih veličina i s proizvodnim jedinicama smještenim u zemlji s velikim domaćim tržištem što im omogućava da ostvare značajnu ekonomiju obujma na nivou proizvodnje, te kad se upravljačke usluge pružaju iz zemlje relativno obilne kvalificiranim radom. Unaprjeđenje ovoga modela ponudili su Bergstrand i Egger (2007) dokazavši postojanje komplementarnosti između FDI i trgovine, čak i između identičnih zemalja, te su utvrdili da trgovina, FDI i prodaja inozemnih podružnica mogu rasti (agregatno) s rastom BDP-a i dviju zemalja ${ }^{4}$.

\section{FDI U HRVATSKOJ I OSTALIM EUROPSKIM TRANZIGIJSKIM ZEMLJAMA}

\section{I. GLOBALNA KRIZA I NJEZIN UTJEGAJ NA JUGOISTOČNU EUROPU}

Financijska i ekonomska kriza imale su snažan negativni utjecaj na međunarodne tijekove kapitala, a posebno FDI. Tijekom samo dvije godine ukupne svjetske strane direktne investicije opale su za cca. 50\% i do kraja 2009. stabilizirale se na razini od nešto više od I,I mlrd. USD-a. Najsnažniji utjecaj krize može se opaziti kod razvijenih zemalja koje su doživjele pad FDI od 60\%, dok su manje razvijene zemlje doživjele relativno malen pad od cca. 15-20\%. U isto vrijeme zemlje JIE ostvarile su pad dolaznih FDI za otprilike 40\%, trenutno bez većih izgleda za skori oporavak, budući je ukupni priljev FDI dostigao razinu od 4,I mlrd. USD-a u 20I0. čime je ostvaren ukupni pad od skoro 70\%. Ovakav negativni razvoj događaja uglavnom je određen prevladavajućim motivima inozemnih ulagača u regiju. Inozemna ulaganja u JIE još uvijek su uglavnom motivirana privatizacijskim projektima i realizirana spajanjima i pripajanjima (M\&A) koja su vrlo osjetljiva na ciklička kretanja i stoga nestabilna u srednjem roku. Aktualni problemi na međunarodnim financijskim tržištima i slabi investicijski izgledi za budućnost dodatno doprinose lošem poslovnom okruženju u regiji, umanjujući na taj način planove ulagača za budućnost.

Tijekovi FDI u JIE dosegnuli su vrhunac 2007, ali su s razvojem krize i padom tijekova kapitala, sve zemlje iz regije ostvarile niži udjel dolaznih FDI u ukupnim ulaganjima. Ipak, ukupno stanje FDI značajno je poraslo i dostiglo 76 mlrd. USD-a u 20IO, pri čemu se Hrvatska ističe kao najznačajniji pojedinačni primatelj u regiji $\mathrm{s}$ udjelom od $45 \%$. Usporavanje ulaganja u JIE može se iščitati i iz opadajućeg broja i vrijednosti investicijskih projekata (kako spajanja i pripajanja, tako i greenfiledulaganja), pri čemu se blagi oporavak može primijetiti u 20Io. godini (tablica I).

\footnotetext{
${ }^{4}$ Temeljem sličnog modela Baltagi, Egger i Pfaffermayr (2007) utvrdili su postojanje četiri tipa FDI koji, osim horizontalnih i vertikalnih FDI, uključuju i izvozne FDI (export-platform FDI) i kompleksne vertikalne FDI (complex-vertical FDI).
} 


\section{TABLICA I.}

Različiti pokazatelji FDI za regiju jugoistočne Europe*

\begin{tabular}{|c|c|c|c|c|c|c|}
\hline Pokazatelj & 2005. & 2006. & 2007. & 2008. & 2009. & 2010. \\
\hline Priljev FDI (mil. USD) & 4.877 & 9.875 & $\mathrm{I} 2.837$ & $\mathrm{I} 2.6 \mathrm{OI}$ & 7.824 & 4.125 \\
\hline Odljev FDI (mil. USD) & 273 & 395 & $\mathrm{I} .448$ & I. 896 & I.37I & 52 \\
\hline Stanje dolaznih FDI (mil. USD) & 26.913 & 46.951 & 74.036 & 67.320 & 77.299 & $76.4 \mathrm{I} 4$ \\
\hline Stanje odlaznih FDI (mil. USD) & 2.139 & 2.545 & 4.200 & 9.644 & II.I7O & 8.775 \\
\hline Priljev FDI (\% ukupnih domaćih ulaganja) & 15,5 & 24,3 & 33 & 27,4 & 21,8 & 13 \\
\hline Odljev FDI (\% ukupnih domaćih ulaganja) & $\mathrm{I}, 4$ & $\mathrm{I}, 3$ & $\mathrm{I}, 3$ & $4, \mathrm{I}$ & 3,8 & 0,2 \\
\hline Stanje dolaznih FDI (\% BDP-a) & 29,8 & 46,3 & 62,7 & 39,7 & 50,6 & 52 \\
\hline Stanje odlaznih FDI (\% BDP-a) & $3, \mathrm{I}$ & 3,2 & 4,3 & 5,7 & 7,3 & 6 \\
\hline $\begin{array}{l}\text { Vrijednost prekograničnih transakcija } \\
\text { spajanja i pripajanja (mil. USD) }\end{array}$ & 955 & 3.942 & 2.192 & 767 & 529 & 266 \\
\hline $\begin{array}{l}\text { Broj prekograničnih transakcija } \\
\text { spajanja i pripajanja (mil. USD) }\end{array}$ & 30 & 39 & 73 & 46 & I7 & I8 \\
\hline Broj greenfield-projekata & 148 & 140 & 156 & $23 \mathrm{I}$ & 136 & 175 \\
\hline
\end{tabular}

* Albanija, Bosna i Hercegovina, Crna Gora, Hrvatska, Makedonija, Srbija.

Izvor: UNCTAD, $20 I I$.

\subsection{DINAMIKA I STRUKTURA DOLAZNIH FDI U ISTOČNOJ EUROPI}

Dinamični priljev FDI označio je razdoblje zrele tranzicije u istočnoj Europi. Najviše pojedinačne godišnje priljeve ostvarile su napredne tranzicijske zemlje poput Poljske, Češke i Mađarske koje se također ističu i u 2OIo. prema stanju dolaznih FDI. U isto vrijeme zemlje JIE ostvarile su znatno slabije priljeve FDI, uglavnom zbog spore ekonomske liberalizacije i institucionalnih reformi, kao i sporog procesa pristupanja EU-u. Među njima samo su Hrvatska i Srbija ostvarile nešto više godišnje priljeve (tablica 2).

\section{TABLica 2.}

Različiti pokazatelji FDI europskih tranzicijskih zemalja (mil. USD)

\begin{tabular}{|c|c|c|c|c|c|c|c|}
\hline \multirow[b]{2}{*}{ Zemlja } & \multicolumn{6}{|c|}{ Priljev FDI } & \multirow{2}{*}{$\begin{array}{c}\text { Stanje FDI } \\
\text { 2010. }\end{array}$} \\
\hline & $\begin{array}{c}\text { 1990-2005. } \\
\text { (kumulativni } \\
\text { priljev) }\end{array}$ & 2006. & 2007. & 2008. & 2009 & 2010. & \\
\hline Češka & 56.297 & 5.463 & 10.444 & $6.45 \mathrm{I}$ & 2.927 & $6.78 \mathrm{I}$ & I29.893 \\
\hline Mađarska & 5O.III & $6.8 \mathrm{I} 8$ & $3.95 \mathrm{I}$ & 7.384 & 2.045 & 2.377 & 91.933 \\
\hline Poljska & 78.477 & 19.603 & $23.56 \mathrm{I}$ & I4.839 & I3.698 & $9.68 \mathrm{I}$ & I93.I4I \\
\hline Slovačka & 20.303 & 4.693 & $3.58 \mathrm{I}$ & 4.687 & -50 & 526 & 50.687 \\
\hline Slovenija & 5.237 & 644 & I.5I4 & I.947 & -582 & 834 & I5.022 \\
\hline Bugarska & I $4.45 \mathrm{I}$ & 7.805 & $\mathrm{I} 2.389$ & 9.855 & $3.35 \mathrm{I}$ & 2.170 & 47.971 \\
\hline Rumunjska & 23.977 & II. 367 & 9.921 & I3.910 & 4.847 & 3.573 & 70.012 \\
\hline Hrvatska & I2.198 & 3.743 & 5.035 & 6.179 & $2.9 \mathrm{II}$ & 583 & 34.374 \\
\hline Albanija & I.709 & 325 & 656 & 988 & 979 & I.097 & 4.355 \\
\hline Bosna i Hercegovina & 2.472 & 766 & 2.080 & 932 & 246 & 63 & 7.152 \\
\hline Makedonija & I. 642 & 433 & 693 & 586 & $2 \mathrm{OI}$ & 293 & 4.493 \\
\hline Srbija & 5.687 & 4.256 & 3.439 & 2.955 & I. 959 & I. 329 & 20.584 \\
\hline Crna Gora & 688 & 622 & 934 & 960 & I. 527 & 760 & 5.459 \\
\hline
\end{tabular}

Izvor: UNCTAD, 2OII.

Prema najnovijim podacima, priljevi FDI u analiziranim zemljama predstavljaju manje od $25 \%$ ukupnih investicija, iako u nekim slučajevima vrijednost ovoga pokazatelja dostiže 30\% (Albanija), ili čak 130\% 
(Crna Gora). Ipak, gospodarska kriza značajno je umanjila oslanjanje na ovaj oblik eksternog financiranja, budući su vrijednosti ovih pokazatelja u nekim zemljama značajno ispod prosjeka EU-a $(9,7 \%)$, odnosno prosjeka razvijenih zemalja općenito $(8,4 \%)$.

Unatoč rastućim odlaznim ulaganjima zemalja poput Mađarske i Slovenije, tranzicijske zemlje općenito su i dalje neto-primatelji FDI. Pokazatelj kumulativnog neto-priljeva FDI po glavi stanovnika otkriva vjerodostojniju sliku uspjeha pojedinih zemalja u privlačenju inozemnog kapitala. U tom pogledu najviši priljev ostvarile su najuspješnije tranzicijske zemlje, ali također Bugarska, Hrvatska, i odnedavno Crna Gora (grafikon I).

\section{GRAFIKON I.}

Kumulativni neto-priljev FDI po glavi stanovnika europskih tranzicijskih zemalja* (u tis. USD-a), I990-20Io.

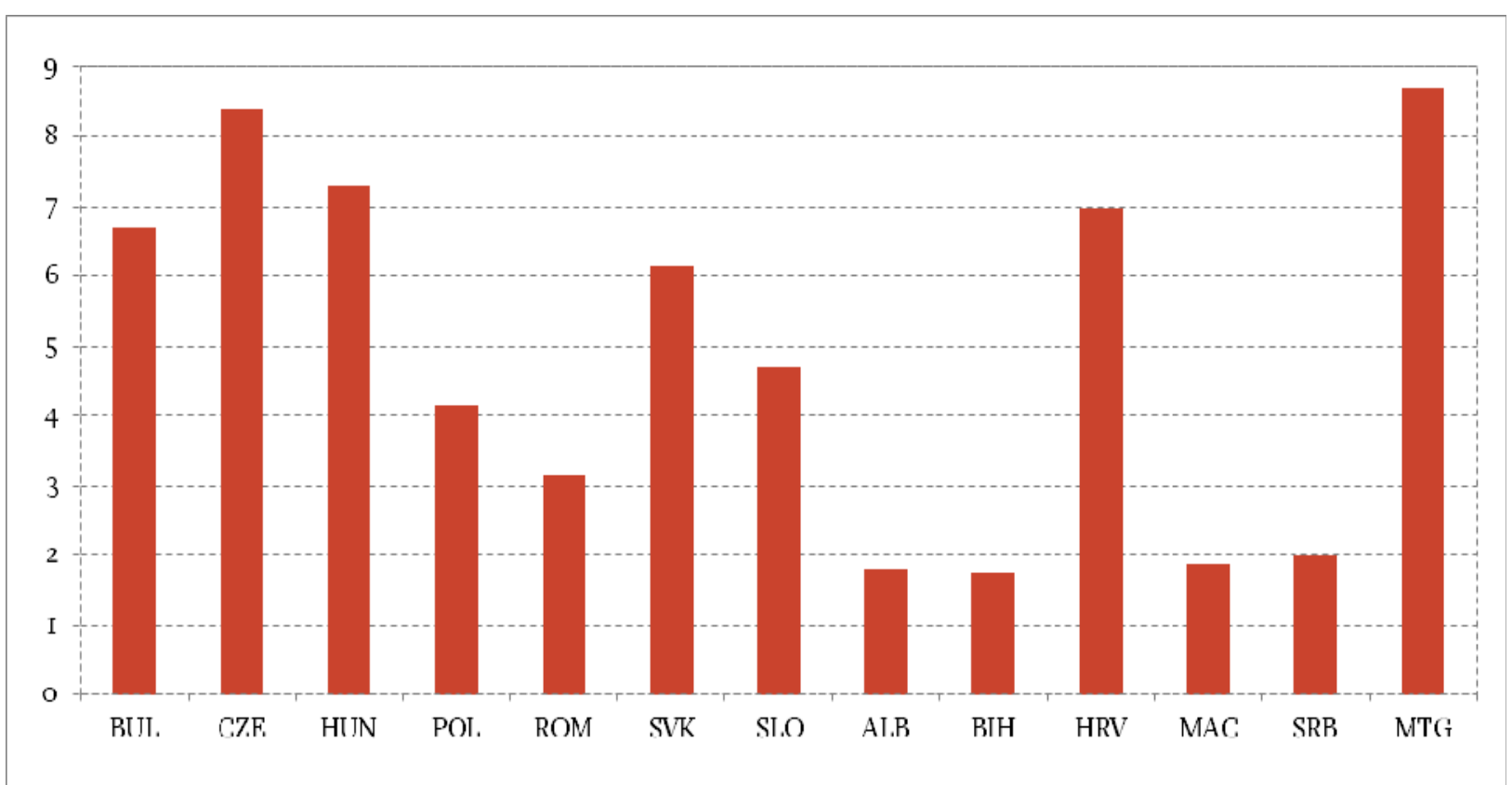

* BUL - Bugarska, CZE - Češka, HUN - Mađarska, POL - Poljska, ROM - Rumunjska, SVK - Slovačka, SLO - Slovenija, ALB - Albanija, BIH - Bosna i Hercegovina, HRV - Hrvatska, MAC - Makedonija, SRB - Srbija, MTG - Crna Gora.

Izvor: UNCTAD, 2OII; IMF, $20 I I$.

Dok indikatori priljeva FDI ukazuju na visinu i dinamiku dolaznih ulaganja, stanje FDI pobliže otkriva realne učinke ostvarenih investicija ${ }^{5}$. Grafikon 2 pokazuje da se u srednjoj i istočnoj Europi malo koja zemlja može usporediti sa Češkom, u pogledu FDI po glavi stanovnika, iza koje slijede Slovačka i Mađarska. U JIE Hrvatska i Crna Gora premašuju prosjek tranzicijskih zemalja, dok preostale u regiji ostvaruju osjetno niže vrijednosti ovoga pokazatelja.

\footnotetext{
${ }^{5}$ Za razliku od kumulativnog priljeva FDI koji predstavlja tek zbroj dolaznih FDI, stanje FDI izračunava se na temelju aktualne tržišne (burzovne) vrijednosti stečenog udjela u poduzeću, oscilacija deviznog tečaja i načela zbrajanja pojedinačno stečenih udjela u poduzeću, koji zajedno mogu premašiti postavljeni prag od Io\% ukupne vrijednosti poduzeća.
} 


\section{GRAFIKON 2.}

Stanje FDI po glavi stanovnika u europskim tranzicijskim zemljama (u tis. USD-a), 2010.

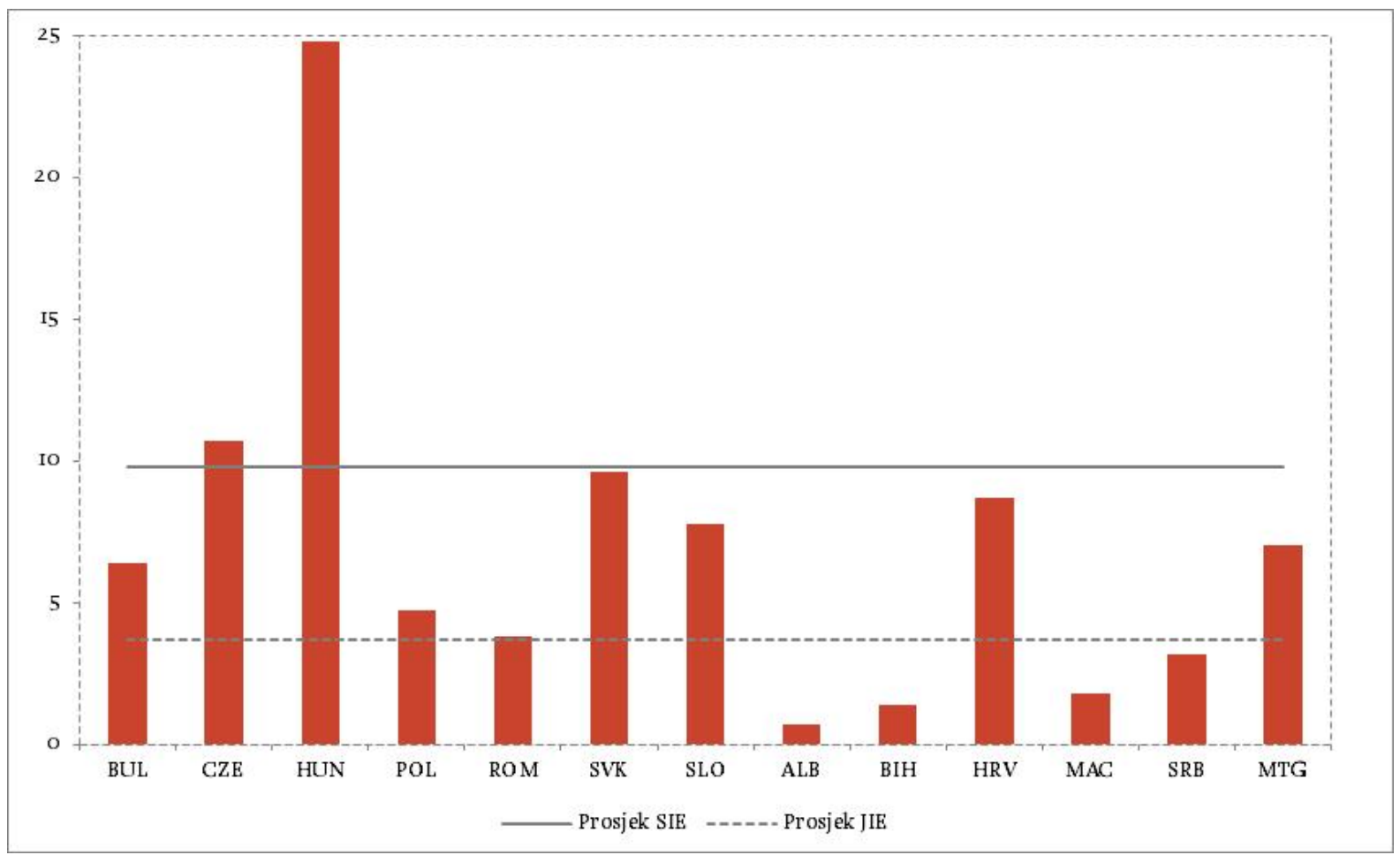

Izvor: UNCTAD, 2OII; IMF, $20 I I$.

Nakon snažnog rasta tijekom druge polovice 1990-ih, strana inozemna ulaganja u Hrvatsku ušla su u razdoblje stabilnog rasta s godišnjim priljevima od približno i mlrd. USD-a. Nakon 2005, priljev FDI u Hrvatsku je snažno rastao i dostigao vrhunac 2008. s nešto više od 4 mlrd. USD-a. Kao posljedica krize, dolazne FDI u Hrvatsku su prepolovljene (2009), što je u nastavku dovelo do snažnog pada na svega 400 mil. USD-a u 2OIO. i tek blagog oporavka od I,5 mlrd. USD-a u 2OII. (CNB, 2OI2).

S obzirom na tip dolaznih ulaganja, u većini analiziranih zemalja, uključujući i Hrvatsku, dominiraju vlasnička ulaganja, dok se značajniji iznosi zadržanih zarada javljaju samo u Češkoj, Estoniji, Litvi i Slovačkoj. Prema strukturi stanja dolaznih FDI po djelatnostima postoje određene razlike između novih članica EU-a i zemalja JIE. Nove članice EU-a ostvarile su otprilike trećinu dolaznih inozemnih ulaganja $\mathrm{u}$ prerađivačku industriju, nakon čega slijede ulaganja $\mathrm{u}$ nekretnine, financijsko posredovanje $\mathrm{i}$ trgovinu. Među zemljama JIE, najveći udjel ulaganja u prerađivačku industriju ostvarile su Bosna i Hercegovina te Makedonija (po 30\%), što je usporedivo s rezultatima naprednih tranzicijskih zemalja, dok je Hrvatska ostvarila udjel FDI u prerađivačku industriju od 25,8\%. Do početka 2OI2. Hrvatska je ostvarila većinu inozemnih ulaganja u sektor usluga (68,4\%), pri čemu se najviše ističu financijsko posredovanje (34\%) i trgovina (13,7\%), nakon kojih slijede ulaganja u nekretnine (Io\%), zatim transport, skladištenje i komunikacije $(8,6 \%)$ te turizam $(2,1 \%)$. Ulaganja u zemlje JIE uglavnom su odlazila u djelatnosti niže dodane vrijednosti poput prehrambene industrije, metalne industrije, prerade nemetalnih mineralnih proizvoda, i u nekim slučajevima, prerade nafte. Istovremeno, napredne tranzicijske zemlje ostvarile su inozemna ulaganja u proizvodnju transportne opreme, električnih i 
optičkih instrumenata, te strojeva i opreme. S obzirom na sektorsku strukturu dolaznih FDI, Hrvatska više sliči skupini zemalja srednje i istočne Europe, budući je od ukupnih dolaznih FDI u prerađivačku industriju 40\% ulaganja realizirala u naftnu industriju, a zatim i proizvodnju nemetalnih mineralnih proizvoda (I7,3\%), prehrambenu (IO,7\%), te farmaceutsku industriju (9,4\%) koja jedina predstavlja iznimku od ovoga općeg obrasca. Regionalna struktura dolaznih FDI u zemlje JIE ukazuje na značajnu prisutnost ulagača iz EU-a, i to posebno onih iz Nizozemske, Austrije i Njemačke (WIIW, 2OI2).

\section{OBILJEŽJA ZEMLJE KAO DETERMINANTE FDI U TRANZIGIJSKIM ZEMLJAMA}

\section{I. RELEVANTNOST KONGEPTA POTENGIJALNIH FDI}

Pitanje gornje granice, ili ekonomskih kapaciteta za primanje novih FDI važno je ekonomsko-političko pitanje za sve zemlje, a posebno za neto-primateljice FDI. Razlozi za to su mnogostruki. FDI posjeduju snažni potencijal za gospodarski rast i razvoj te se obično ističu među strateškim ciljevima mnogih manje razvijenih zemalja. Dok su napredne tranzicijske zemlje iz srednje i istočne Europe ostvarile pozitivne efekte prelijevanja inozemnih ulaganja na domaće gospodarstvo, i uspješno prošle kroz strukturne i ekonomske reforme, koje su ih vodile prema članstvu u EU-u, zemlje JIE nisu uspjele iskoristiti prisutnost inozemnog kapitala, ili su ostvarile značajnije priljeve FDI relativno kasno. Zbog sporih ekonomskih i institucionalnih reformi i još uvijek neostvarenog članstva u EU-u, za zemlje JIE postaje važno utvrditi faktore o kojima ovisi visina i kvaliteta priljeva FDI, kao i njihove stvarne kapacitete u prihvaćanju novih FDI u budućnosti ${ }^{6}$. Čak štoviše, FDI omogućava ostvarivanje priljeva kapitala bez pritisaka na eksterne pozicije zemlje primateljice (Ramirez, 2006; Chakrabarti, 200I). Konačno, nakon "prvog vala” priljeva FDI, uglavnom povezanih s privatizacijskim projektima i usmjerenih na strateško tržišno pozicioniranje inozemnih ulagača, gospodarstva JIE trebaju se razviti u poželjna ulagačka odredišta s dugoročno stabilnim priljevima inozemnog kapitala. To zahtijeva utvrđivanje najvažnijih faktora koji određuju ekonomski kapacitet jedne zemlje u privlačenju novih FDI. Ipak, neizvjesnosti na međunarodnim tržištima ne doprinose jednostavnoj realizaciji gore navedenog cilja. Spori oporavak globalnih FDI, rastuća privlačnost novih investicijskih destinacija, kao i pomak fokusa inozemnih ulagača od prerađivačke industrije k primarnom sektoru i uslugama, snažno će determinirati stanje na međunarodnim tržištima kapitala u srednjem i dugom roku?

Privlačenje FDI postala je međunarodno kompetitivna aktivnost za vlade zemalja (Dunning i Narula, 1997) koja zahtijeva sagledavanje kako trendova na međunarodnim tržištima kapitala, i kapaciteta zemalja primateljica u prihvaćanju FDI, tako i faktora koji određuju visinu i strukturu dolaznih FDI. Štoviše, utvrđivanje potencijala za rast FDI uspoređivanjem s uspješnijim zemljama (npr. novim zemljama članicama EU-a), trebalo bi ukazati na preostale ekonomske i institucionalne reforme nužne

\footnotetext{
${ }^{6}$ U skladu sa Vinerovom tradicijom koja prepoznaje učinke stvaranja i skretanja trgovine, mnoge studije su pokušale utvrditi učinke ekonomskog integriranja na FDI. Općenito se može reći da ekonomsko integriranje doprinosi rastućim FDI zemalja koje su u procesu integriranja, doduše bez dokazanog negativnog učinka na treće zemlje (Kreinin i Plummer, 2008; Baltagi, Egger i Pfaffermayr, 2008; Brento, Di Mauro i Lücke, 1999; Buch, Kokta i Piazolo, 2003; Brouwer, Paap i Viaene, 2008).

${ }^{7} \mathrm{O}$ anti-cikličkim efektima FDI vidjeti u: Levy Yeyati, Panizza i Stein (2007), te Frenkel, Funke i Stadtmann (2004).
} 
za povećanje atraktivnosti lokanog tržišta za nova ulaganja $^{8}$. S obzirom na stanje FDI u odnosu na broj stanovnika, Hrvatska je relativno dobro pozicionirana među tranzicijskim zemljama, budući je vrijednost njezina pokazatelja FDI per capita (9.70o USD) usporediva s prosjekom deset novih zemalja članica EU-a, te je dvostruko veća od onoga zemalja nečlanica EU-a. To Hrvatsku čini vodećom primateljicom FDI u regiji (grafikon 3).

\section{GRAFIKON 3.}

Stanje FDI per capita europskih tranzicijskih zemalja* (u tis. USD-a), 2010.

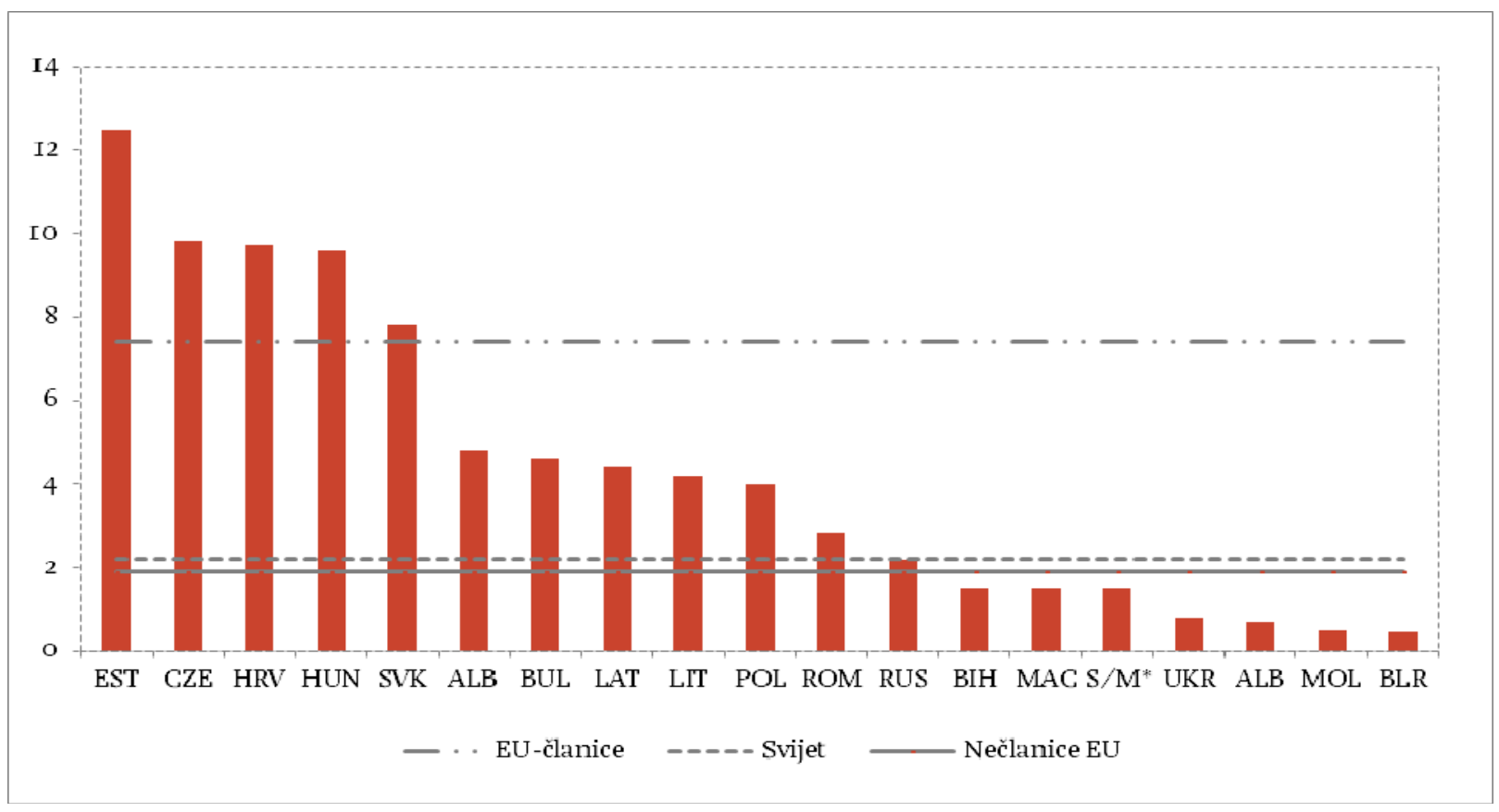

*EST - Estonija, LAT - Latvija, LIT - Litva, RUS - Rusija, S/M - Srbija i Crna Gora, UKR - Ukrajina, MOL - Moldova, BLR - Bjelorusija. Izvor: UNCTAD, $20 I I$.

Relativni indikatori pokazuju da je Hrvatska ostvarila značajne iznose FDI, kako u usporedbi s deset novih zemalja članica EU-a, tako i u odnosu na preostale tranzicijske zemlje (grafikon 4). S obzirom na udjel FDI u BDP-u, kao i priljev FDI u ukupnim ulaganjima u zemlji, napredne tranzicijske zemlje srednje i istočne Europe su visoko rangirane, dok manje napredne zemlje zauzimaju lošije pozicije $s$ udjelima od cca. 40\% ili manje. Hrvatska je i u ovom slučaju relativno dobro pozicionirana sa skoro 60\% udjela ostvarenih FDI u BDP-u, i relativno niskom razinom priljeva FDI, mjereno udjelom u ukupnim ulaganjima.

Prema udjelu stanja FDI u trgovinskim tijekovima, analizirane zemlje mogu se podijeliti u dvije skupine. Prva skupina, s udjelima FDI u izvozu iznad Ioo\%, obuhvaća manje napredne zemlje iz JIE, uključujući i Hrvatsku. S druge strane, uspješnije zemlje i nove članice EU-a grupirane se na dnu liste što pokazuje da njihove dolazne FDI nisu značajno premašile njihove izvozne kapacitete (grafikon 5).

\footnotetext{
${ }^{8}$ O učincima mjera ekonomske politike u privlačenju FDI, vidjeti u: Borensztein, De Gregorio i Lee (I998), te Yu, Chang i Fan (2007).
} 


\section{GRAFIKON 4.}

Stanje FDI (\% BDP-a; 20IO) i prosječni godišnji priljev FDI (\% ukupnih ulaganja; 199o-20IO) u europskim tranzicijskim zemljama

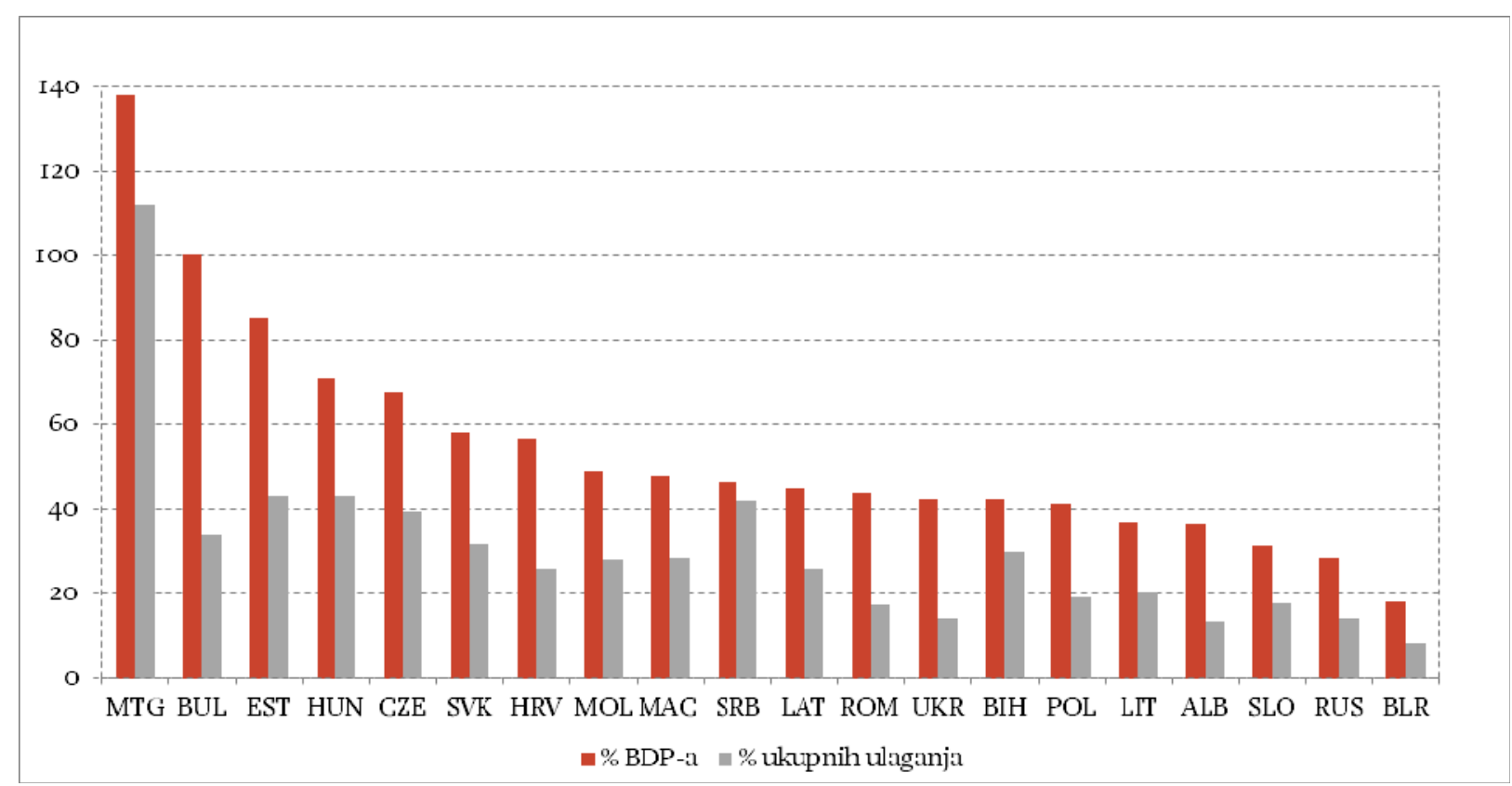

Izvor: UNCTAD, $20 I I$.

\section{GRAFIKON 5.}

Stanje FDI u europskim tranzicijskim zemljama (\% izvoza, \% uvoza), 2010.

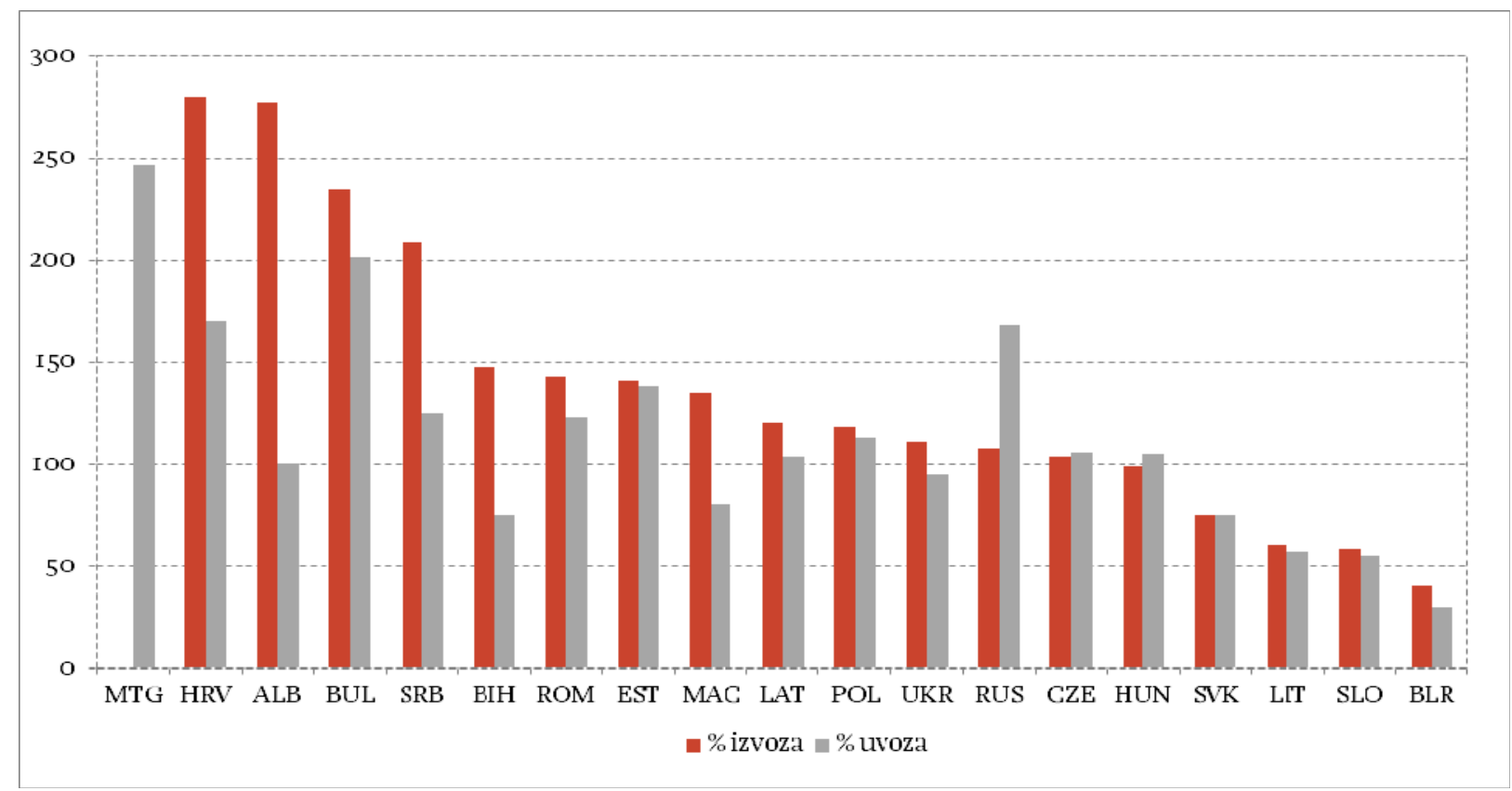

Izvor: UNCTAD, $20 I I$

Podaci pokazuju da su neke zemlje ostvarile relativno visoke nivoe FDI, mjereno u terminima njihovih domaćih tržišta i njihovih apsorpcijskih kapaciteta u prihvaćanja novih FDI, te da bi za njih moglo biti teško prihvatiti nove FDI u budućnosti bez pokretanja snažnijeg gospodarskog rasta. 


\subsection{REFERENCE NA SLIČNU EMPIRIJSKU LITERATURU}

Utvrđivanje potencijalnih FDI usko je povezano s utvrđivanjem determinanti priljeva FDI. Empirijske studije koje uključuju današnje tranzicijske zemlje iz razdoblja prije 199o-ih relativno su oskudne i uglavnom fokusirane na temeljne ekonomske varijable, uključujući i troškovne faktore. Wang i Swain (1995) analizirali su determinante dolaznih FDI u Mađarsku i Kinu (1978-1992) i dokazali relevantnost veličine i potencijala rasta domaćeg tržišta, zajedno s tipičnim troškovnim faktorima (nadnice, trgovinske barijere, devizni tečaj). Ang (2008) je u studiji o FDI u Maleziji došao do sličnog zaključka o važnosti uvjeta na domaćem tržištu, kao i faktora koji određuju proizvodne troškove. Ova studija također pokazuje da su dolazne FDI u Maleziji rasle neovisno o problemu rastućeg rizika zemlje i azijske financijske krize. Slična analiza FDI u Čileu tijekom 1990-ih dokazala je relevantnost BDP-a iz prethodnog razdoblja kao faktora koji utječe na dolazne FDI (vremenski pomaknuta varijabla BDP-a), implicirajući da se očekivanja gospodarskog rasta formiraju na temelju ostvarene razine razvoja iz prethodnog razdoblja (Ramirez, 2006). Ova se studija pritom snažno referira na eksterne pozicije zemlje (bilanca plaćanja i eksterna ranjivost), kao i na političku stabilnost, kao determinante dolaznih FDI.

Chakrabarti (200I) je analizirao I35 zemlje, prema podacima iz 1994, i utvrdio da troškovni faktori snažno determiniraju dolazne FDI, pri čemu su se rezultati, ipak pokazali značajno osjetljivima na promjene u stanju makroekonomske stabilnosti (inflacija, proračunski deficit, vanjski dug, itd.). Moosa i Cardak (2006) proveli su sličnu analizu i dokazali relevantnost stupnja razvijenosti, dohotka i trgovinske otvorenosti u privlačenju FDI.

Bellak, Librecht i Riedl (2008) istražili su faktore koji utječu na tijekove FDI u zemljama srednje i istočne Europe. Na temelju panel-gravitacijskog pristupa, ova je studija potvrdila relevantnost tipičnih gravitacijskih varijabli i troškovnih faktora kao aproksimacije troškovne konkurentnosti zemlje primateljice FDI. Analiza je dokazala da najsnažniji utjecaj na zavisnu varijablu dolazi od temeljne "gravitacijske specifikacije" regresijske jednadžbe, ukazujući na taj način da troškovni faktori nude široko područje za vladine intervencije. Garibaldi, Mora, Sahay i Zettlemayer (200I) proveli su analizu velikog uzorka tranzicijskih zemalja tijekom I990-ih. Pritom su diferencirali greenfield i financijske investicije, i proveli dvije neovisne regresije s tim zavisnim varijablama. Detaljna specifikacija eksplanatornih varijabli uključuje pokazatelje makroekonomske stabilnosti, indikatore institucionalnih reformi, i specifične strukturne varijable koje se referiraju na stupanj razvoja financijskih tržišta. Ovaj rad naglašava važnost ekonomskih temelja (poput makroekonomske stabilnosti, ekonomskih reformi, liberalizacije trgovine i modela privatizacije), kao determinanti greenfield-investicija. Carstensen i Toubal (2004) krenuli su od pretpostavke da se razlike između zemalja srednje i istočne i jugoistočne Europe $u$ privlačenju FDI ne mogu objasniti samo putem "tradicionalnih varijabli" (BDP, troškovni faktori i nivo obrazovanja), te su uveli specifične tranzicijske varijable, koje su se pokazale relevantnim u dinamičkom panel modelu.

U analizi koja se odnosi na Hrvatsku, Deichmann (2013) je pokušao utvrditi determinante dolaznih FDI tijekom drugog desetljeća tranzicije (2000-2009). On je pomoću regresijske jednadžbe gravitacijskog 
tipa analizirao bilateralne hrvatske FDI i utvrdio da aglomeracijske snage, odnosi s EU-om, povijesne veze i bilateralni trgovinski odnosi determiniraju dolazne FDI u Hrvatsku, pri čemu nije uspio dokazati relevantnost tipičnih gravitacijskih varijabli.

Analize učinka ekonomskog integriranja redovito su uključivale dilemu o komplementarnosti ili supstitutibilnosti FDI i trgovine ${ }^{9}$. U pokušaju davanja odgovora na to pitanje Di Mauro (2000) je kreirala model koji je kombinirao aspekte gravitacijske jednadžbe i varijabli rastućih prinosa na obujam, u analizi bilateralnih tijekova FDI između zemalja članica OECD-a. Ova skupina varijabli uključivala je složene indikatore kao što su sličnost u veličini BDP-a dviju zemalja, veličina "ekonomskog prostora" (zbroj BDP-a dviju zemalja), i indeks razlika relativne raspoloživosti proizvodnih faktora. Osim što je potvrdila relevantnost varijabli koje proizlaze iz nove teorije trgovine, Di Mauro (2000) je pokazala da devizni tečaj nema negativnog utjecaja na tijekove FDI (dok god je on relativno stabilan), kao niti carine (implicirajući na taj način izostanak motiva FDI za "preskakanje carina”). Ovi rezultati nisu iznenađujući s obzirom na analizirani uzorak razvijenih otvorenih ekonomija sa stabilnim deviznim tečajevima. Christie (2003) je koristio sličnu metodologiju u analizi bilateralnih dolaznih FDI u zemlje srednje i istočne i jugoistočne Europe u cilju utvrđivanja uzorka FDI. Rezultati su pokazali da su FDI u napredne tranzicijske zemlje (SIE) bile uglavnom horizontalnog tipa, dok uzorak FDI u zemljama JIE nije bilo moguće sa sigurnošću utvrditi. Dalje, rad je potvrdio relevantnost sličnosti u veličini tržišta, "efektu veličine”, i relativnim razlikama u raspoloživosti proizvodnih faktora, kao objašnjenja razlika u investicijskim tijekovima između zemalja.

Buch, Kokta i Piazolo (2003) uglavnom su se bavili primjenom koncepta "potencijalnih" FDI na procjenu učinaka proširenja EU-a (zemlje SIE) na stare članice (Portugal, Španjolska). Procjenjujući tipičnu gravitacijsku jednadžbu bilateralnih tijekova FDI, zaključili su da nije ostvareno "preusmjeravanje" FDI od starih prema novim zemljama članicama, budući su dokazali da potencijalna, ili teorijski predviđena razina FDI općenito odgovaraju aktualnoj, odnosno ostvarenoj razini. Brenton, Di Mauro i Lücke (1999) došli su do sličnog zaključka s obzirom na procijenjenu potencijalnu razinu FDI za Češku, Mađarsku, Poljsku i Rumunjsku. U analizi integracijskih učinaka na FDI u zemljama SIE, Clausing i Dorobantu (2005) potvrdili su pozitivan utjecaj pristupanja EU-u, kao i relevantnost troškovnih faktora i ostalih ekonomskih "fundamentalnih" veličina (BDP, dohodak i trgovinska otvorenost).

Ostale analize primarno su fokusirane na procjenu potencijalnih FDI i uključuju radove Demekas, Horváth, Ribakova i Wu (2007), te Borrmann, Jungnickel i Keller (2005). Demekas i dr. (2007) promatrali su veliki uzorak zemalja tijekom kratkog perioda (2000-2002), pri čemu je analiza FDI nevezanih uz privatizacijske projekte, kao zavisne varijable, provedena na agregatnoj razini, kao i za parove zemalja. Rezultati, pak nisu pokazali statistički značajnu razliku između zemalja srednje i istočne i jugoistočne Europe po pitanju determinanti priljeva FDI. Zanimljivu analizu potencijalnih FDI ponudili su Borrmann i dr. (2005) koji su se primarno fokusirali na odlazne njemačke FDI u pokušaju utvrđivanja aktualnih, u odnosu na potencijalne FDI iz Njemačke u četiri zemlje primateljice iz SIE. Novina ovoga

${ }^{9}$ Za daljnje informacije, vidjeti: Hejazi i Safarian (200I), Lipsey (2002), Lin (1995), Graham (1996) i Portes (2007). 
pristupa je u tome što se uzima u obzir ne samo tržišni potencijal zemalja primateljica, već i njihovih susjednih tržišta. Općenito se može zaključiti da su realizirane njemačke FDI u analiziranim zemljama veće od procijenjene razine potencijalnih. Babić i Stučka (200I) istraživali su determinante dolaznih FDI u Hrvatsku i utvrdili da najsnažniji utjecaj na priljev dolazi od aglomeracijskih učinaka i dohotka, a potom i pokazatelja kreditnog rejtinga. Varijabla trgovinske otvorenosti nije značajna u analiziranom modelu, što nije iznenađujuće $s$ obzirom na nedovršeni proces liberalizacije trgovine Hrvatske $u$ periodu na koji se analiza odnosi (1992-1999).

Navedene studije pokazuju da su zemlje JIE bile puno manje analizirane, nego uspješnije tranzicijske zemlje iz srednje i istočne Europe, te da se Hrvatska rijetko našla u fokusu tih analiza. Stoga, ovaj rad doprinosi postojećoj literaturi o FDI u tranzicijskim zemljama na način da se fokusira na zemlje JIE koje još uvijek zaostaju u terminima dolaznih FDI i svojih lokacijskih obilježja. U tom nastojanju, izvornost rada proizlazi iz analize determinanti dolaznih FDI kombiniranjem tipičnih gravitacijskih varijabli, s jedne i varijabli rastućih prinosa na obujam, s druge strane. Rad, nadalje koristi napredne zemlje iz srednje i istočne Europe za usporedbu i izračunavanje potencijalne razine dolaznih FDI u Hrvatsku, prema individualnim zemljama porijekla. Za razliku od sličnih empirijskih studija, ovaj rad uzima $u$ obzir veću skupinu zemalja u analizi bilateralnih FDI i koristi duže vremenske serije podataka (I99o2004). Duljina je primarno određena prvim valom proširenja EU-a iz 2004, budući bi u suprotnim analiza išla u smjeru procjene integracijskih učinaka na tijekove FDI, što je izvan postavljenog cilja ovoga rada (vidjeti: Medvedev, 20II; Kim, 2007; Petroulas, 2007).

\subsection{SPEGIFIKAGIJA MODELA I REZULTATI}

U svrhu objašnjavanja faktora koji determiniraju tijekove FDI u tranzicijskim zemljama, sljedeći model uključuje tri skupine nezavisnih varijabli: tipične gravitacijske varijable, varijable bazirane na rastućim prinosima na obujam, i institucionalne varijable (detaljnije o varijablama i izvorima podataka vidjeti u tablici Ai u prilogu).

Varijable gravitacijskog tipa formulirane su prema Linnemannu (1966.) i uključuju BDP, stanovništvo i dohodak, kako zemlje porijekla, tako i zemlje primateljice, ali također i faktore koji mogu dodatno utjecati na bilateralne ekonomske odnose, bilo pozitivno (zajednička granica, sudjelovanje u ekonomskim integracijama, kulturološke sličnosti), ili negativno (trgovinski i transakcijski troškovi koji se uobičajeno aproksimiraju prostornom udaljenošću). BDP, kao apsolutna mjera veličine tržišta i ostvarenog stupnja gospodarskog razvoja, određuje opći nivo ekonomske efikasnosti gospodarstva i njegove kapacitete $\mathrm{u}$ ostvarivanju ekonomije obujma, što je posebno važno za male ekonomije (Chakrabarti, 200I; Ang, 2008). Stoga, očekuje se značajni utjecaj BDP-a na tijekove FDI. Aproksimirajući potencijale ekonomije obujma, BDP će, prema očekivanjima, izazivati manji pritisak na odljev FDI u slučaju velikih ekonomija, dok će suprotno biti slučaj za male razvijene ekonomije. U slučaju zemlje primateljice, rastući BDP će očekivano pozitivno utjecati na dolazne FDI. Varijabla dohotka (BDP/capita), kao pokazatelj kupovne moći na lokalnom tržištu, ali i kao aproksimacija 
lokalnih troškova rada, može imati pozitivni i negativni učinak ${ }^{\mathrm{TO}}$. Stanovništvo zemlje porijekla i zemlje odredišta obično imaju međusobno suprotni učinak na bilateralne tijekove FDI. Dok velika populacija zemlje porijekla može utjecati na smanjenje zanimanja ulagača za inozemnim tržištima, velika populacija zemlje primateljice može taj nedostatak interesa preokrenuti tako da potakne generiranje novih ulaganja. Uloga varijable udaljenosti u gravitacijskom modelu FDI nije uvijek jednoznačna. U smislu "hipoteze blizine i koncentracije" (proximity-concentration hypothesis) i pod pretpostavkom korištenja FDI u svrhu zamjene za postojeće trgovinske tijekove, može se očekivati pozitivna međuovisnost udaljenosti i FDI. U jednostavnijem slučaju u kojemu kapital cirkulira između zemalja na različitom stupnju razvoja, može se očekivati negativni odnos između udaljenosti i FDI. Varijabla zajedničke granice može, na isti način, pozitivno utjecati na tijekove FDI. Pridruživanje EU-u će očekivano imati pozitivni utjecaj, budući taj proces implicira gospodarske reforme i restrukturiranje, primjenu zajedničkih politika, kao i pravnu i institucionalnu prilagodbu standardima EU-a.

Analiza također uključuje varijable bazirane na rastućim prinosima na obujam, nesavršenoj konkurenciji i diferencijaciji proizvoda (Helpman i Krugman, 1986) koje u empirijskom smislu omogućuju diferenciranje različitih tipova FDI (horizontalne i vertikalne), kao i motiva za ulaganje (traženje tržišta, ili traženje efikasnosti). Ove kompozitne varijable bazirane su na BDP-u zemlje porijekla i zemlje primateljice pa su, stoga prikladne za analizu bilateralnih tijekova ulaganja (Di Mauro, 20oo). Varijabla sličnosti BDP-a zemalja (GDP-similarity) objašnjava u kojoj mjeri sličnost u ekonomskoj veličini zemalja doprinosi generiranju bilateralnih tijekova FDI. Posljedično, što su zemlje međusobno sličnije, to će međusobno kreirati veće investicijske tijekove. Varijabla veličine BDP-a dviju zemalja (GDP-size), koja zbrajanjem BDP-a dviju zemalja mjeri veličinu njihova bilateralnog ekonomskog prostora, trebala bi imati pozitivni utjecaj. Konačno, varijabla razlika u relativnoj raspoloživosti proizvodnih faktora između zemalja (GDP/capita-difference) trebala bi prikazati utjecaj različitih struktura proizvodnih faktora po zemljama na strukturu i visinu dolaznih FDI. Sukladno tome, velike razlike u raspoloživosti proizvodnih faktora između zemalja ukazivale bi na prisutnost vertikalnih, dok bi male razlike indicirale prisutnost horizontalnih FDI.

Cilj institucionalnih varijabli je obuhvatiti specifična obilježja tranzicijskih zemalja poput liberalizacije trgovine i režima deviznog tečaja, privatizacije, i udjela trgovine s netranzicijskim zemljama. U tom kontekstu, ugovorni odnosi s EU-om mogli bi se razumjeti i kao indirektna mjera institucionalnih reformi, budući one uključuju pravne i institucionalne prilagodbe standardima razvijenih zemalja, koje usto predstavljaju vjerodostojno jamstvo poticajnog ulagačkog okruženja.

Analiza koja slijedi primarno je fokusirana na specifična obilježja zemalja kao determinanti dolaznih FDI i ima za cilj utvrđivanje najznačajnijih faktora koji su odredili bilateralne tijekove u istočnoj Europi tijekom razdoblja u kojemu su neke od analiziranih zemalja postale značajni primatelji FDI (I9962004). U tom smislu analiza uključuje $\mathrm{I2}$ zemalja primateljica ${ }^{\mathrm{II}}$ i pet pojedinačno najznačajnijih

\footnotetext{
Io Eaton i Tamura (1996) su utvrdili da FDI preferiraju zemlje srednjeg dohotka u odnosu na zemlje niskog dohotka s niskim apsorpcijskim kapacitetom lokalnog tržišta, ili zemlje visokog dohotke koje imaju visoke proizvodne troškove.

${ }^{\text {II }}$ Ne temelju ugovornih odnosa s EU-om ova skupina uključuje: Bugarsku, Češku, Estoniju, Hrvatsku, Latviju, Livu, Mađarsku, Makedoniju, Poljsku, Rumunjsku, Slovačku i Sloveniju. Do 2004. većina ovih zemalja završila je pristupne pregovore (Bugarska i
} 
inozemnih ulagača u zemlje istočne Europe (Nizozemska, Njemačka, Austrija, Francuska i SAD). Zavisna varijabla standardnog višestrukog regresijskog modela je stanje dolaznih FDI koje uključuje sve tipove ulaganja (privatizacijska i neprivatizacijska ulaganja). Ova varijabla je prikladnija za analize duljih vremenskih serija koje su fokusirane na determinante FDI. Varijabla stanja FDI je obično stabilnija kroz vrijeme, i za razliku od varijable tijeka rijetko poprima negativne vrijednosti ili nulu ${ }^{\mathrm{I2}}$. Korelacijska matrica nezavisnih varijabli nalazi se $\mathrm{u}$ tablici A2 u prilogu.

Regresijska jednadžba logaritamskog (ln) tipa u svim varijablama (osim dummy-varijabli) izračunata je metodom najmanjih kvadrata:

$$
\text { Ln inwardFDIstock }=\text { Const. }+\beta_{1} \operatorname{Ln} X_{I}+\beta_{2} X_{2}+\ldots+\beta_{n} \operatorname{Ln} X_{n}+\mu
$$

i dala je rezultate prikazane u tablici 3 .

\section{TABLicA 3.}

Rezultati regresijske analize za europske tranzicijske zemlje (1996-2004)

\begin{tabular}{|c|c|c|c|c|c|c|}
\hline & \multicolumn{3}{|c|}{ Model I } & \multicolumn{3}{|c|}{ Model 2} \\
\hline & Koeficijent & St. greška & t-statistika & Koeficijent & St. greška & t-statistika \\
\hline konstanta & $-34,784$ & 2,787 & $\begin{array}{r}-\mathrm{I} 2,085 \\
\left(\mathrm{t}^{*}{ }_{0,005}=2,576\right)\end{array}$ & $-27,996$ & 3,017 & $\begin{array}{r}-9,279 \\
\left(t^{*}{ }_{0,005}=2,576\right)\end{array}$ \\
\hline Ln GDP host & 1,399 & $0,08 \mathrm{I}$ & $\begin{array}{r}17,282 \\
\left(t^{*}{ }_{0,005}=2,576\right)\end{array}$ & & & \\
\hline Ln GDP home & O,I47 & 0,057 & $\begin{array}{r}2,580 \\
\left(t^{*}{ }_{0,005}=2,576\right)\end{array}$ & & & \\
\hline Ln POP host & & & & & & \\
\hline Ln POP home & & & & & & \\
\hline Ln GDPcap host & $-0,516$ & $\mathrm{O}, \mathrm{I} 27$ & $\begin{array}{r}-4,079 \\
\left(t^{*}{ }_{0,005}=2,576\right)\end{array}$ & & & \\
\hline Ln GDPcap home & $\mathrm{I}, 98 \mathrm{I}$ & 0,257 & $\begin{array}{r}7,700 \\
\left(t^{*}{ }_{0,005}=2,576\right)\end{array}$ & & & \\
\hline GDPsim_Ln & & & & $\mathrm{I}, 46 \mathrm{I}$ & 0,082 & $\begin{array}{r}\mathrm{I} 7,875 \\
\left(\mathrm{t}^{*}{ }_{0,005}=2,576\right)\end{array}$ \\
\hline GDPsize_Ln & & & & $\mathrm{I}, 593$ & 0,087 & $\begin{array}{r}\mathrm{I} 8,399 \\
\left(\mathrm{t}^{*}{ }_{0,005}=2,576\right)\end{array}$ \\
\hline GDPcapDIF_Ln & & & & $-0,802$ & 0,160 & $\begin{array}{r}-5,000 \\
\left(t^{*}{ }_{0,005}=2,576\right)\end{array}$ \\
\hline Ln DIST & $-0,674$ & 0,088 & $\begin{array}{r}-7,69 \mathrm{I} \\
\left(\mathrm{t}^{*}{ }_{0,005}=2,576\right)\end{array}$ & $-0,639$ & o,093 & $\begin{array}{r}-6,875 \\
\left(\mathrm{t}^{*}{ }_{0,005}=2,576\right)\end{array}$ \\
\hline Ln relDIST & & & & & & \\
\hline Ln relDIST GDP & & & & & & \\
\hline Ln ULC & & & & & & \\
\hline Ln ULC ERadj & & & & & & \\
\hline Ln ULC PPPadj & & & & & & \\
\hline Ln OPEN g & & & & & & \\
\hline Ln OPEN gs & 1,395 & $0,25 \mathrm{I}$ & $\begin{array}{r}5,557 \\
\left(\mathrm{t}^{*}{ }_{0,005}=2,576\right)\end{array}$ & 1,383 & 0,245 & $\begin{array}{r}5,654 \\
\left(t^{*}{ }_{0,005}=2,576\right)\end{array}$ \\
\hline Ln PRIVAT rev & O,I5O & O,057 & $\begin{array}{r}2,6 \mathrm{I} 7 \\
\left(\mathrm{t}^{*}{ }_{0,005}=2,576\right)\end{array}$ & $\mathrm{O}, \mathrm{I} 7 \mathrm{I}$ & 0,058 & $\begin{array}{r}2,966 \\
\left(t^{*}{ }_{0,005}=2,576\right)\end{array}$ \\
\hline Ln TRADE nont & 1,307 & 0,325 & $\begin{array}{r}4,026 \\
\left(t^{*}{ }_{0,005}=2,576\right)\end{array}$ & I,555 & 0,363 & $\begin{array}{r}4,28 \mathrm{I} \\
\left(\mathrm{t}^{*}{ }_{0,005}=2,576\right)\end{array}$ \\
\hline
\end{tabular}

Rumunjska bile su izgledni kandidati za članstvo), dok su Hrvatska i Makedonija imale potpisane Sporazume o stabilizaciji i pridruživanju.

${ }_{{ }^{12}}$ Ipak, neke studije, koje se uglavnom bave mjerama ekonomske politike, koriste varijablu tijeka FDI kao zavisnu varijablu (Bellak i dr., 2008; Grosse i Trevino, 2005; Ang, 2008; MacDermott, 2007). 


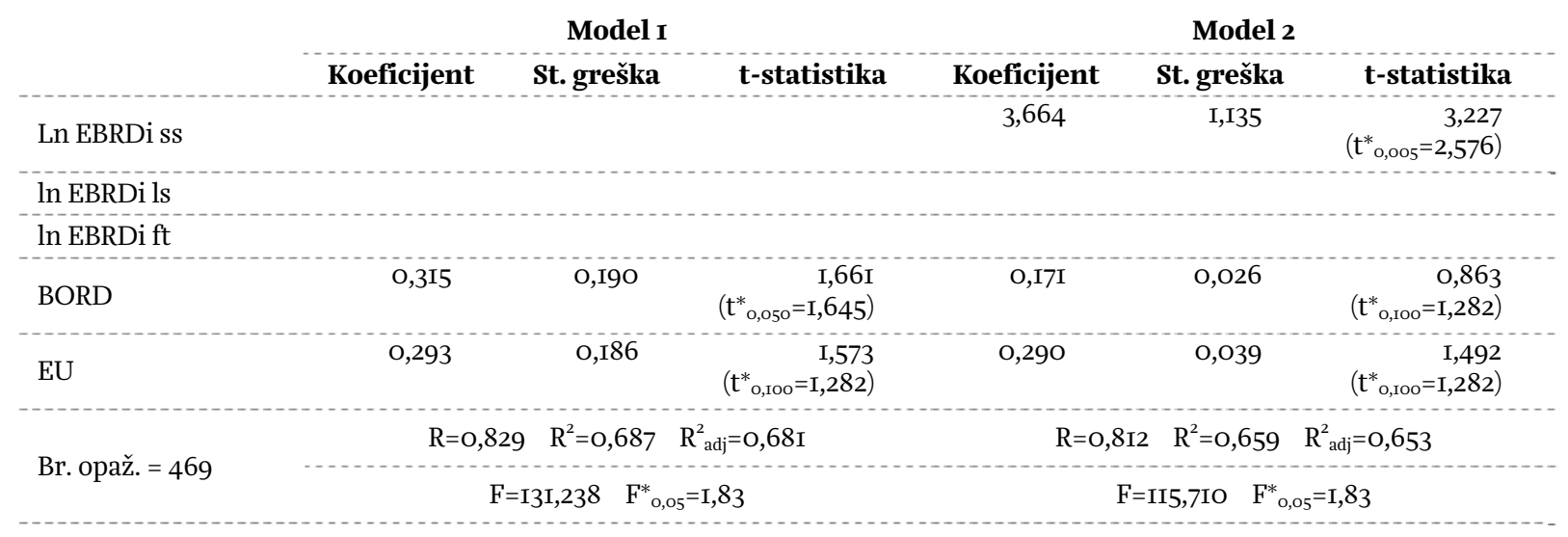

Izvor: Autor.

Dobiveni rezultati potvrđuju teorijska očekivanja o relevantnosti odabranih varijabli, kao i njihovim predznacima i statističkoj značajnosti, u objašnjavanju dolaznih FDI u tranzicijskim zemljama. Model I potvrđuje "gravitacijsko ponašanje" što znači da su tipični push-and-pull-faktori odigrali značajnu ulogu u određivanju visine i smjera kretanja FDI, što je konzistentno s rezultatima ostalih analiza kao npr. Bellak i dr. (2008). Model 2, utemeljen na pretpostavci nesavršene konkurencije i rastućih prinosa na obujam, otkriva da motivi poput ekonomije obujma, ili disperzije poslovnih aktivnosti po zemljama $u$ skladu s njihovom faktorskom intenzivnošću i relativnom raspoloživošću proizvodnih faktora, dodatno objašnjavaju snage koje su determinirale tijekove FDI u istočnoj Europi.

Najsnažniji utjecaj na dolazne FDI u gravitacijskom modelu dolazi od stupnja razvijenosti (BDP) i dohotka zemlje porijekla i zemlje odredišta inozemnih ulaganja. Ovaj rezultat potvrđuje da su zemlje visokog dohotka i obiljem kapitala generirale veća direktna ulaganja, te da su ih najviše privukle ulagačke mogućnosti u velikim ekonomijama s niskim troškovima proizvodnje. Za razliku od postojeće empirijske literature, ova analiza potvrdila je negativni predznak i statističku značajnost BDP-a po stanovniku zemlje primateljice, što je u skladu s gore rečenim, te ukazuje da su visoki dohodak (i visoke nadnice) negativno utjecale na dolazne FDI u tranzicijske zemlje. Snažni utjecaj također dolazi od trgovinske otvorenosti, čime se naglašava važnost slobodnog pristupa međunarodnom tržištu kao elementa u privlačenju FDI. To se dalje potvrđuje i prisutnošću varijable trgovine s netranzicijskim zemljama u finalnoj specifikaciji modela. Ova varijabla odražava stupanj trgovinske reorijentacije tranzicijskih zemalja prema razvijenim tržištima kao posljedice rastuće (međunarodne) konkurentnosti i uspješnog gospodarskog restrukturiranja kroz koje su prošle. To može, barem dijelom, objasniti zaostajanje nekih zemalja iz JIE u smislu skromnog priljeva ulaganja. Očekivano, udaljenost je imala negativni utjecaj, ukazujući da prostorna blizina doprinosi generiranju većih FDI. Štoviše, ulazak dummy-varijable za zajedničku granicu u finalnu specifikaciju modela to potvrđuje, te ukazuje da susjedne zemlje imaju snažnije potencijale za ovu vrstu ekonomske suradnje. Konačno, druga dummy-varijabla, koja ima za cilj obuhvatiti pozitivni utjecaj različitih aspekata odnosa s EU-om, u ovom se slučaju potvrđuje kao relevantna za tranzicijske zemlje, kao što to pokazuju Deichmann (20I3), te Clausing i Dorobantu (2005). Ovakav rezultat je očekivan, budući je poznato da pristupanje 
EU-u otvara slobodan pristup velikom tržištu, potiče pravne i institucionalne reforme, i daje vjerodostojnost zemlji kao poželjnoj investicijskoj lokaciji.

Specifikacija modela bazirana na konceptu rastućih prinosa na obujam potvrđuje relevantnost varijabli koje pokazuju da veličina tržišta, kao i razlike između zemalja igraju značajnu ulogu u kreiranju bilateralnih FDI (slično kao i kod Di Mauroa, 200o). To se dokazuje visokom vrijednošću procijenjenog parametra varijable koja prikazuje veličinu BDP-a dviju zemalja (GDP-size), kao mjere njihovog "zajedničkog ekonomskog potencijala". Ipak, varijable koje "mjere" sličnost između BDP-a dviju zemalja (GDP-similarity, GDP/cap-difference) ostvarile su nešto slabiji utjecaj na dolazne FDI u tranzicijske zemlje. Relativno niska vrijednost procijenjenog parametra za varijablu GDP/cap-difference pokazuje da stupanj sličnosti dohotka nije značajno utjecao na nivo realiziranih FDI, dok negativni predznak ukazuje da je većina FDI bila horizontalnog tipa, odnosno motivirana traženjem novih tržišta. S obzirom na dominantni udjel zemalja srednje i istočne Europe u dolaznim FDI ukupno analiziranog uzorka zemlja, ovakav rezultat nije iznenađujući i u skladu je s nalazima studije Christie (2003). Ipak, ova finalna specifikacija modela ne uključuje zajedničku granicu, budući je ova varijabla ušla u model, ali s niskom statističkom značajnošću.

Što se tiče institucionalnih varijabli, jedina koja je ušla $u$ finalnu specifikaciju modela je ona privatizacije na malo koja je ujedno ostvarila i najvišu procijenjenu vrijednost parametra. Ostale institucionalne varijable poput privatizacije na veliko, ili indeksa liberalizacije režima deviznog tečaja i trgovine nisu se pokazale relevantnim, pa su stoga izostavljene iz modela. Moguće objašnjenje ovakvog ishoda eventualno proizlazi iz različitih modela privatizacije velikih poduzeća koje su različite zemlje primjenjivale (npr. neposredna prodaja, nasuprot “insajderskoj” privatizaciji). S druge strane, izostanak pokazatelja deviznog tečaja iz modela može se eventualno objasniti njegovom relativnom stabilnošću (slično kao i u Di Mauro, 200o). Ipak, ova pitanja zahtijevaju daljnje istraživanje, eventualno i unaprjeđenjem prezentiranih analitičkih modela, u smislu izbora alternativnih varijabli, metodologije mjerenja varijabli poput metode privatizacije, deviznog tečaja ili jediničnih troškova rada (vidjeti: Bellak i dr., 2008), ili uzimajući u obzir dinamični karakter FDI.

Gore spomenuti modeli korišteni su za izračunavanje stanja potencijalnih hrvatskih FDI. Pritom, vrijednosti potencijalnih dolaznih FDI za razdoblje 2005-Io. izračunati su temeljem korištenja aktualnih makroekonomskih podataka i najviših vrijednosti indeksa institucionalnih reformi (prema metodologiji EBRD-a), na agregatnoj razini, i za pojedine zemlje porijekla FDI $^{\text {I3 }}$. Analiza uključuje I9 zemalja koje u 20Io. ostvaruju otprilike 9o\% stanja ukupnih dolaznih FDI.

Rezultati iz tablice 4 pokazuju da je, temeljem gravitacijskog modela (model I), realizirani nivo stanja FDI kroz godine uglavnom veći od procijenjenog, doduše uz poneke iznimke. Rezultate za 2009. i 2010. treba pažljivo interpretirati zbog globalne ekonomske krize koja je, očigledno, umanjila kapacitete za stvaranje, ali i prihvaćanje novih FDI, što se dodatno potvrđuje i kroz pad globalnih tijekova ulaganja. Tijekom tih godina, i temeljem aktualnih podataka, dolazne FDI u Hrvatsku ostvarene su na približno

\footnotetext{
${ }^{13}$ Potencijalno stanje FDI definira se kao vrijednost pokazatelja koja bi postojala kada bi ukupne dolazne FDI u Hrvatsku (u cijelosti) bile određene varijablama i procijenjenim parametrima modela (Nilsson, 200o; Fidrmuc i Fidrmuc, 2003).
} 
30\% višoj razini, nego što je procijenjeno modelom. U 2006. i 2007. ta je razlika mnogo manja (IO-20\%), dok podaci za 2005. i 2008. , koje prethode krizi, ukazuju čak na "oskudicu” realiziranog nivoa FDI, u odnosu na vrijednosti procijenjene modelom ${ }^{\mathrm{I} 4}$.

\section{TABLica 4.}

Razina realiziranog i procijenjenog stanja dolaznih FDI u Hrvatskoj (mlrd. USD)

\begin{tabular}{|c|c|c|c|c|c|c|}
\hline Stanje dolaznih FDI & 2005. & 2006. & 2007. & 2008. & 2009. & 2010. \\
\hline Ostvareno & 13,7 & 22,2 & 35,6 & 28,6 & $3 \mathrm{I}, \mathrm{I}$ & 30,6 \\
\hline Procijenjeno (model I) & 15,8 & 20,2 & 30,4 & 40,5 & 23,7 & 23,8 \\
\hline
\end{tabular}

Izvor: Autor.

\section{TABlica 5.}

Odnos nivoa stanja potencijalnih i realiziranih dolaznih FDI u Hrvatsku prema zemlji porijekla (model I)

\begin{tabular}{|c|c|c|c|c|c|c|}
\hline Zemlja porijekla FDI & 2005. & 2006. & 2007. & 2008. & 2009. & 2010. \\
\hline Austrija & 0,36 & 0,43 & 0,24 & $0,5 \mathrm{I}$ & 0,28 & 0,27 \\
\hline Mađarska & $\mathrm{O}, \mathrm{I} 6$ & $\mathrm{O}, \mathrm{I} 4$ & O,I8 & 0,25 & 0,09 & 0,06 \\
\hline Njemačka & 0,53 & 0,79 & $0,5 \mathrm{I}$ & 0,83 & 0,43 & 0,42 \\
\hline Nizozemska & 0,82 & 0,25 & $\mathrm{O}, 3 \mathrm{I}$ & 0,44 & 0,27 & 0,35 \\
\hline Slovenija & 0,75 & 0,86 & $\mathrm{I}, \mathrm{I} 3$ & 1,28 & 0,72 & 0,67 \\
\hline Italija & I,68 & 0,56 & 3,06 & 3,69 & $2, \mathrm{IO}$ & $\mathrm{I}, 8 \mathrm{O}$ \\
\hline Ujedinjeno Kraljevstvo & 1,53 & 0,80 & 0,75 & $\mathrm{I}, 32$ & 0,58 & 0,62 \\
\hline Francuska & 5,36 & 0,90 & I,O9 & $\mathrm{I}, 26$ & 0,77 & $0,7 \mathrm{I}$ \\
\hline Švedska & 7,85 & 2,72 & 2,82 & 6,37 & 2,53 & 4,18 \\
\hline Švicarska & 6,75 & $3,8 \mathrm{I}$ & $4, \mathrm{I} 6$ & 8,24 & 6,46 & 7,13 \\
\hline Belgija & 15,79 & $25, \mathrm{IO}$ & 3,67 & 6,91 & 5,56 & 3,73 \\
\hline Sjedinjene Američke Države & 0,68 & $\mathrm{I}, 33$ & $\mathrm{I}, 8 \mathrm{I}$ & 2,18 & $\mathrm{I}, 6 \mathrm{O}$ & $\mathrm{I}, 8 \mathrm{I}$ \\
\hline Irska & $\mathrm{I} 6,38$ & 13,92 & 19,78 & 19,44 & $7,4 \mathrm{I}$ & 3,26 \\
\hline Danska & 9,59 & $\mathrm{I} 2,82$ & $\mathrm{I} 2,24$ & I4,35 & IO,OO & 7,12 \\
\hline Rusija & $\mathrm{I}, \mathrm{O} 3$ & 0,82 & 0,50 & $\mathrm{I}, \mathrm{O} 4$ & 0,36 & 0,45 \\
\hline Norveška & 198,47 & I53,05 & 71,70 & 77,64 & 25,46 & 26,39 \\
\hline Španjolska & 8,37 & $7, \mathrm{OI}$ & 5,44 & $8,7 \mathrm{I}$ & 5,46 & 4,40 \\
\hline Bosna i Hercegovina & 0,05 & 0,07 & 0,12 & 0,42 & 0,20 & - \\
\hline Izrael & 9,98 & II,I5 & $\mathrm{I} 2,82$ & 9,40 & 5,66 & 6,16 \\
\hline
\end{tabular}

Izvor: Autor.

Analiza podataka po individualnim zemljama indirektno potvrđuje relativno snažni gravitacijski karakter dolaznih FDI u Hrvatsku, kako je to prikazano u tablici 5. Odnos potencijalnih i realiziranih FDI s vrijednosti manjom od jedan pokazuje da je zemlja primila više FDI, nego što je predviđeno modelom, dok vrijednosti pokazatelja iznad jedan ukazuju na postojanje neiskorištenih kapaciteta za primanje novih FDI. Susjedne i geografski bliske zemlje Hrvatskoj (Austrija, Mađarska, Njemačka i Slovenija) ulagale su više, nego što je teoretski očekivano, dok većina ostalih zemalja, prema prikazanim podacima, još uvijek nije ostvarila puni kapacitet u realizaciji bilateralnih tijekova FDI u Hrvatsku. S obzirom na izbor vremenski promjenjivih varijabli u modelu (BDP, trgovinska otvorenost, privatizacija

\footnotetext{
${ }^{\text {I4 }}$ Kad se promotre samo neprivatizacijske FDI, Demekas i dr. (2007) utvrđuju postojanje relativno malog jaza između aktualnih i potencijalnih FDI u Hrvatskoj.
} 
i ugovorni odnosi s EU-om), može se tvrditi da će kapaciteti Hrvatske u pokretanju gospodarskog rasta i strukturnih reformi, kao i nastavku institucionalnih reformi, uključujući i članstvo u EU-u, biti ključni faktori u privlačenju novih FDI u budućnosti.

\section{ZAKLJUǦNA RAZMATRANJA}

Nedavna iskustva nepovoljnog utjecaja globalne ekonomske krize na tijekove FDI i slabi izgledi za njihov oporavak u srednjem roku, doveli su u pitanje prevladavajući koncept gospodarskog rasta $u$ istočnoj Europi. On je uključivao tržišnu ekspanziju putem ekonomske integracije, rast vanjskog duga, i inozemna ulaganja vezana uz privatizacijske projekte. S obzirom na promjene u svjetskim tijekovima FDI i tražnju novih ulagačkih mogućnosti, kako s aspekta ekonomskih djelatnosti, tako i s aspekta krajnjih odredišta za ulaganja, uloga FDI kao generatora budućeg ekonomskog rasta može biti dovedena $u$ pitanje.

Rezultati empirijskih analiza pokazali su da faktori gravitacijskog tipa, ali i faktori bazirani na rastućim prinosima na obujam, mogu ponuditi objašnjenje tijekova FDI u istočnoj Europi. To znači da su veličina tržišta, trgovinska otvorenost i zemljopisna blizina zemalja imale snažni utjecaj na bilateralne tijekove FDI. Ovakav rezultat je očekivan s obzirom na razdoblje $u$ kojemu je analiza provedena. Početne tranzicijske godine i otvaranje novih poslovnih mogućnosti na tržištima tradicionalno oskudnim kapitalom, učinili su veličinu domaćeg tržišta, međunarodne trgovinske odnose i mogućnosti sudjelovanja u privatizacijskim projektima, glavnim čimbenicima u privlačenju FDI. Ugovorni odnosi s EU-om pokazali su se relevantnim, te su pomogli naprednim tranzicijskim zemljama da privuku dodatna ulaganja. Varijable bazirane na rastućim prinosima na obujam ponudile su nešto sofisticiranije objašnjenje prema kojemu su sličnost u dostignutom stupnju gospodarskog razvoja, kao i stupanj sličnosti dohotka između zemalja ostvarili pozitivni utjecaj na bilateralne FDI. S obzirom na to, pokazalo se da su FDI, ostvareni tijekom 1990-ih i dalje, bili u naravi horizontalnog tipa u potrazi za širenjem na nova tržišta.

Iako rad nema izravne ekonomsko-političke implikacije, razumijevanje faktora koji determiniraju bilateralne tijekove FDI, može pomoći ekonomskoj politici u osmišljavanju strategija za privlačenje FDI. Procijenjene vrijednosti potencijalnih FDI u Hrvatskoj otkrivaju da se daljnji porast dolaznih FDI može ostvariti samo putem ostvarivanja daljnjeg ekonomskog rasta i rastuće trgovinske otvorenosti što uključuje i sasvim izvjesno integriranje Hrvatske u EU ${ }^{15}$. Stoga, napori na polju ekonomske politike trebali bi biti usmjereni na stvaranje uvjeta za održivi ekonomski rast čime bi se smanjio razvojni jaz prema potencijalnim zemljama porijekla FDI. Ove spoznaje u skladu su i s “analizom praga” (threshold analysis) koju su proveli Demekas i dr. (2007), a prema kojoj se Hrvatska, kao srednje razvijena zemlja, trenutno treba više koncentrirati na veličinu tržišta (uključujući i slobodni pristup EU-tržištu) i makroekonomsku stabilnost, dok bi se u budućnosti veća pažnja trebala posvetiti faktorima koji utječu na konkurentne proizvodne troškove kao što su porezi, devizni tečaj i produktivnost rada, kao

\footnotetext{
${ }^{15}$ Ovaj zaključak nalazi potvrdu i kod Bellak i dr. (2008) te Brenton i dr. (1999) za napredne tranzicijske zemlje u ranoj fazi razvoja, sličnoj fazi razvoja u kojoj se trenutno nalazi Hrvatska.
} 
determinantama priljeva FDI. “Obični” gravitacijski faktori koji su do sada determinirali tijekove FDI vjerojatno će prestati dominirati u budućnosti, s daljnjim razvojem Hrvatske i ostalih zemalja iz JIE. Ipak, daljnja istraživanja u tom smislu bila bi korisna, kao i neka unaprjeđenja prezentiranog analitičkog modela. To bi eventualno uključivalo diferenciranje FDI prema tipu (greenfield, nasuprot brownfield, i neprivatizacijska ulaganja) i ekonomskoj djelatnosti, kao i širi izbor institucionalnih varijabli, i to ne samo specifičnih tranzicijskih, već i onih koje pobliže opisuju kvalitetu međunarodno konkurentnog poslovnog okruženja. Analiza troškovnih faktora kao determinanti dolaznih FDI predstavljaju daljnje područje za buduća istraživanja zemalja JIE i Hrvatske. U smislu gore navedenog, globalna recesija ukazuje na važnost postizanja održivog gospodarskog rasta kao glavnog preduvjeta za rastuću apsorpcijsku sposobnost lokalnog gospodarstva za nove FDI, što je u skladu i s konceptom rastućih prinosa na obujam i sličnosti u stupnju ekonomskog razvoja kao snaga koje doprinose generiranju međunarodnih ulaganja. 


\section{Prilog}

\section{Tablica AI.}

Opis varijabli i izvori podataka

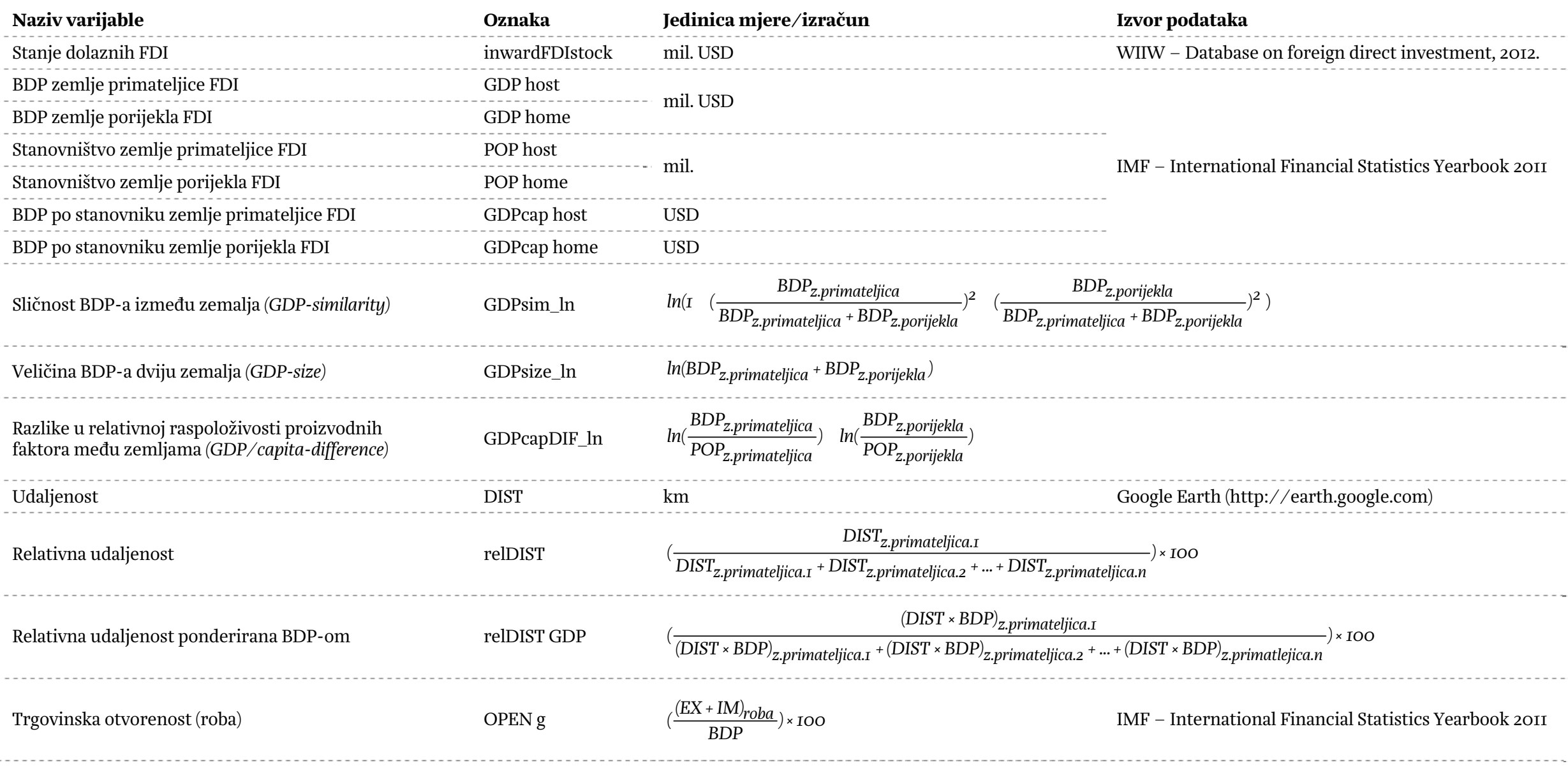




\begin{tabular}{|c|c|c|c|}
\hline Trgovinska otvorenost (roba i usluge) & OPEN gs & $\left(\frac{(E X+I M)_{\text {roba }}+(E X+I M)_{\text {usluge }}}{B D P}\right) \times I O O$ & \\
\hline Jedinični troškovi rada & ULC & $\%(2000 .=100)$ & \multirow{3}{*}{ Astrov i dr. (2006) } \\
\hline Jedinični troškovi rada korigirani za devizni tečaj & ULC ERadj & $\%(2000 .=100)$ & \\
\hline $\begin{array}{l}\text { Jedinični troškovi rada korigirani za paritet } \\
\text { kupovne moći }\end{array}$ & ULC PPPadj & $\%(2000 .=100)$ & \\
\hline Zajednička granica & BORD & $\begin{array}{l}\text { dummy } \\
(\mathrm{DA}=\mathrm{I}, \mathrm{NE}=\mathrm{O})\end{array}$ & Google Earth map (http://earth.google.com) \\
\hline Ugovorni odnosi s EU-om & $\mathrm{EU}$ & $\begin{array}{l}\text { dummy } \\
\text { (DA=I za punopravno članstvo, Europski sporazum, } \\
\text { Sporazum o stabilizaciji i pridruživanju, ili ugovor o } \\
\text { pristupanju, inače } \mathrm{NE}=\mathrm{O} \text { ) }\end{array}$ & MFAEI - Croatia on the road to the EU, 2009. \\
\hline Prihodi od privatizacije & PRIVAT rev & kumulativno kao postotak BDP-a & \multirow{5}{*}{$\begin{array}{l}\text { EBRD - Transition Report 2002; } \\
\text { EBRD - Transition Report 2009 }\end{array}$} \\
\hline Trgovina s netranzicijskim zemljama & TRADE nont & postotak ukupnog volumena trgovine & \\
\hline Privatizacija na malo (mala poduzeća) & EBRDi ss & \multirow{3}{*}{$\begin{array}{l}\text { indeks } \\
(\text { min. }=1, \max .=4,3)\end{array}$} & \\
\hline Privatizacija na veliko (velika poduzeća) & EBRDi ls & & \\
\hline $\begin{array}{l}\text { Liberalizacija režima deviznog tečaja } \\
\text { i vanjske trgovine }\end{array}$ & EBRDi ft & & \\
\hline
\end{tabular}

Izvor: Autor. 


\section{Tablica A2.}

Korelacijska matrica nezavisnih varijabli

\begin{tabular}{|c|c|c|c|c|c|c|c|c|c|c|c|c|c|c|c|c|c|}
\hline $\begin{array}{l}\text { Oznaka } \\
\text { varijable }\end{array}$ & $\begin{array}{l}\text { GDP } \\
\text { host }\end{array}$ & $\begin{array}{c}\text { GDP } \\
\text { home }\end{array}$ & $\begin{array}{l}\text { POP } \\
\text { host }\end{array}$ & $\begin{array}{c}\text { POP } \\
\text { home }\end{array}$ & $\begin{array}{c}\text { GDPcap } \\
\text { host }\end{array}$ & $\begin{array}{c}\text { GDPcap } \\
\text { home }\end{array}$ & DIST & $\begin{array}{c}\text { OPEN } \\
\mathrm{g}\end{array}$ & $\begin{array}{l}\text { OPEN } \\
\text { gs }\end{array}$ & ULC & BORD & EU & $\begin{array}{c}\text { PRIVAT } \\
\text { rev }\end{array}$ & $\begin{array}{c}\text { TRADE } \\
\text { nont }\end{array}$ & $\begin{array}{l}\text { EBRDi } \\
\text { ss }\end{array}$ & $\begin{array}{l}\text { EBRDi } \\
\quad \text { ls }\end{array}$ & $\underset{\mathrm{ft}}{\text { EBRDi }}$ \\
\hline GDP host & I,OOO & & & & & & & & & & & & & & & & \\
\hline GDP home & 0,084 & I,OOO & & & & & & & & & & & & & & & \\
\hline POP host & 0,888 & 0,052 & I,OOO & & & & & & & & & & & & & & \\
\hline POP home & 0,080 & 0,990 & o,o6I & I,OOO & & & & & & & & & & & & & \\
\hline $\begin{array}{l}\text { GDPcap } \\
\text { host }\end{array}$ & O,I76 & 0,089 & -O,I34 & o,o66 & $\mathrm{I}, \mathrm{OOO}$ & & & & & & & & & & & & \\
\hline $\begin{array}{l}\text { GDPcap } \\
\text { home }\end{array}$ & o,096 & 0,529 & $-0,064$ & 0,468 & 0,322 & I,OOO & & & & & & & & & & & \\
\hline DIST & 0,035 & 0,958 & 0,046 & 0,952 & $-0,008$ & 0,494 & I,OOO & & & & & & & & & & \\
\hline OPEN g & $-0,323$ & 0,027 & $-0,539$ & o,OIO & 0,344 & O,I74 & $-\mathrm{O}, \mathrm{O} 2 \mathrm{I}$ & I,OOO & & & & & & & & & \\
\hline OPEN gs & $-0,4 \mathrm{OI}$ & 0,007 & $-0,609$ & -о,оiо & 0,296 & O,I57 & $-0,032$ & 0,954 & I,OOO & & & & & & & & \\
\hline ULC & 0,056 & 0,052 & $-0,025$ & o,OI8 & $\mathrm{O}, 2 \mathrm{IO}$ & 0,194 & o,009 & $0,22 \mathrm{I}$ & o,196 & I,OOO & & & & & & & \\
\hline BORD & O,I4I & $-0, I 78$ & 0,058 & $-0,184$ & O,I59 & $-0, I 88$ & $-0,253$ & O,I45 & O,IIO & O,OI5 & I,OOO & & & & & & \\
\hline $\mathrm{EU}$ & 0,156 & o,ol9 & O,I64 & O,OOI & 0,058 & O,I06 & 0,003 & 0,092 & 0,085 & 0,286 & 0,036 & $\mathrm{I}, \mathrm{OOO}$ & & & & & \\
\hline PRIVAT rev & $0,25 \mathrm{I}$ & o,093 & O,II2 & 0,072 & O,I44 & $\mathrm{O}, \mathrm{I} 28$ & $\mathrm{O}, \mathrm{O} 2 \mathrm{I}$ & 0,378 & 0,286 & 0,326 & O,II8 & 0,224 & $\mathrm{I}, \mathrm{OOO}$ & & & & \\
\hline $\begin{array}{l}\text { TRADE } \\
\text { nont }\end{array}$ & $0,4 \mathrm{I} 8$ & 0,062 & 0,468 & 0,064 & 0,219 & -O,IO3 & $\mathrm{O}, \mathrm{O} 4 \mathrm{I}$ & -O,III & -O,IO4 & O,I57 & O,IIO & O,I4I & 0,246 & $\mathrm{I}, \mathrm{OOO}$ & & & \\
\hline EBRDi ss & O,I77 & 0,400 & $-0,170$ & 0,027 & 0,559 & 0,277 & $-0,038$ & 0,426 & 0,423 & o,065 & O,I23 & 0,022 & O,I9O & $-\mathrm{O}, \mathrm{I} 62$ & I,OOO & & \\
\hline EBRDi ls & 0,077 & 0,460 & $-0,690$ & 0,025 & O,I44 & O,I75 & $-0,005$ & 0,679 & 0,682 & $0,34 \mathrm{I}$ & 0,170 & $0,38 \mathrm{I}$ & 0,512 & 0,208 & 0,326 & I,OOO & \\
\hline EBRDi ft & 0,308 & 0,084 & 0,227 & 0,067 & 0,368 & 0,129 & o,oI6 & 0,094 & 0,072 & 0,366 & O,IIO & 0,258 & 0,416 & 0,447 & 0,238 & $\mathrm{O}, 4 \mathrm{II}$ & $\mathrm{I}, \mathrm{OOO}$ \\
\hline
\end{tabular}

Izvor: Autor. 


\section{REFERENGE}

I. Ang, J. B., 2008. Determinants of foreign direct investment in Malaysia. Journal of Policy Modelling, 30(I), str. 85-I89. doi: http://dx.doi.org/I0.IOI6/j.jpolmod.2007.06.0I4

2. Astrov, V. [i dr.], 2006. Strong growth, driven by exports in the NMS and by consumption in the future EU members. Wiener Institut für Wirtschaftsvergleiche, Research Reports, br. 325.

3. Babić, A. and Stučka, T., 20oI. Panel analysis of FDI determinants in European transition countries. Privredna kretanja i ekonomska politika, II(87), str. 3I-60.

4. Bačić, K., Račić, D. and Ahec-Šonje, A., 2004. The effects of FDI on recipient countries in Central and Eastern Europe. Privredna kretanja i ekonomska politika, I4(IOo), str. 59-96.

5. Baltagi, B. H., Egger, P. and Pfaffermayr, M., 2007. Estimating models of complex FDI: Are there third-country effects?. Journal of Econometrics, I4O(I), str. 26o-28I. doi: http://dx.doi.org/IO.IOI6/j.jeconom.2006.09.009

6. Baltagi, B. H., Egger, P. and Pfaffermayr, M., 2008. Estimating regional trade agreement effects in an interdependent world. Journal of Econometrics, I45(I-2), str. 194-208. doi: http://dx.doi.org/Io.IOI6/j.jeconom.2008.05.017

7. Baniak, A., Cukrowski, J. and Herczyński, J., 2005. On the determinants of foreign direct investment in transition economies. Problems of Economic Transition, 48(2), str. 6-28.

8. Barrel, R. and Pain, N., 1999. Domestic institutions, agglomerations and foreign direct investment in Europe". European Economic Review, 43(4-6), str. 925-934. doi: http://dx.doi.org/IO.IOI6/Sool4-292I(98)oolo5-6

9. Barrios, S. and Strobl, E., 2002. Foreign direct investment and productivity spillovers: Evidence from the Spanish experience. Weltwirtschaftliches Archiv, I38(3), str. 459-48I. doi: http://dx.doi.org/IO.IOO7/BFO2707949

Io. Bellak, C., Librecht, M. and Riedl, A., 2008. Labour costs and FDI flows into Central and Eastern European countries: A survey of the literature and empirical evidence. Structural Change and Economic Dynamics, I9(I), str. 17-37. doi: http://dx.doi.org/Io.IoI6/j.strueco.2007.03.00I

II. Bergstrand, J. H. and Egger, P., 2007. A knowledge-and-physical-capital model of international trade flows, foreign direct investment and multinational enterprises. Journal of International Economics, 73(2), str. 278-308. doi: http://dx.doi.org/Io.IoI6/j.jinteco.2007.03.004

I2. Borensztein, E., De Gregorio, J. and Lee, J.-W., I998. How does foreign direct investment affect economic growth?. Journal of International Economics, 45(I), str. II5-I35. doi: http://dx.doi.org/IO.IoI6/Soo22-I996(97)ooo33-O

I3. Borrmann, C., Jungnickel, R. and Keller, D., 2005. What gravity models can tell us about the position of German FDI in Central and Eastern Europe. Hamburg Institute of International Economics, Discussion Paper, br. 328.

I4. Brainard, L., 1993. A simple theory of multinational corporations and trade with a trade-off between proximity and concentration. National Bureau of Economic Research, Working Paper, br. 4269 .

15. Brainard, L., 1997. An empirical assessment of the proximity-concentration trade-off between multinational sales and trade. American Economic Review, 87(4), str. 520-544.

16. Braunerhjelm, P. and Svensson, R., 1996. Host country characteristics and agglomeration in foreign direct investment. Applied Economics, 28(7), str. 833-840. doi: http://dx.doi.org/IO.IO80/000368496328272

17. Brenton, P., Di Mauro, F. and Lücke, M., 1999. Econometric integration and FDI: An empirical analysis of foreign investment in the EU and in Central and Eastern Europe. Empirica, 26(2), str. 95-I2I. doi: http://dx.doi.org/IO.IO23/A:I007006429600

18. Brouwer, J., Paap, R. and Viaene, J.-M., 2008. The trade and FDI effects of EMU enlargement. Journal of International Money and Finance, 27(2), str. I88-208. doi: http://dx.doi.org/IO.IOI6/j.jimonfin.2007.I2.005

19. Buch, C. M., Kokta, R. M. and Piazolo, D., 2003. Foreign direct investment in Europe: Is there redirection from the South to the East?. Journal of Comparative Economics, 3I(I), str. 94-Io9. doi: http://dx.doi.org/IO.IOI6/SoI47-5967(O2)oool3-6

20.Carr, D. L., Markusen, J. R. and Maskus, K. E., 1998. Estimating the knowledge-capital model of the multinational Enterprise. National Bureau of Economic Research, Working Paper, br. 6773.

2I. Carstensen, K. and Toubal, F., 2004. Foreign direct investment in Central and Eastern European countries: A dynamic panel analysis. Journal of Comparative Economics, 32(I), str. 3-22. doi: http://dx.doi.org/IO.IOI6/j.jce.2003.II.OOI 
22. Chakrabarti, A., 200I. The determinants of foreign direct investment: Sensitivity analysis of cross-country regressions. Kyklos, 54(I), str. 89-II4. doi: http://dx.doi.org/IO.IIII/I4676435.OOI42

23. Christie, E., 2003. Foreign direct investment in Southeast Europe. Wiener Institut für internationale Wirtschaftsvergleiche, Working Paper, br. 24.

24. Clausing, K. A. and Dorobantu, C. L., 2005. Re-entering Europe: Does European Union candidacy boost foreign direct investment?. Economics of Transition, I3(I), str. 77-IO3. doi: http://dx.doi.org/IO.IIII/j.I468-035I.2005.00208.x

25. GNB - Croatian National Bank. http://www.hnb.hr [Pristup: 30. 05. 2012.].

26. Deichmann, J. I., 2013. Origins of foreign direct investment in Croatia: Application of an expanded gravity model. u: A. Karasavvoglou and P. Polichronidou, urednici, 20I3. Balkan and Eastern European countries in the midst of the global economic crisis. Berlin, Heidelberg: Springer-Verlag, str. 3-2I.

27. Demekas, D. G. [et al.], 2007. Foreign direct investment in European transition economies - The role of policies. Journal of Comparative Economics, 35(2), str. 369-386. doi: http://dx.doi.org/Io.IOI6/j.jce.2007.03.005

28. Derado, D., Škudar, A. and Rakušić, S., 2OII. Regional aspects of FDI in Croatia. Ninth International Conference on Challenges of Europe: Growth and Competitiveness - Reversing the Trends Proceedings: PDF on CD ROM with full papers (str. 263-292), University of Split, Faculty of Economics, Split - Bol, 26.-28. 05. 2011.

29. Di Mauro, F. 2000. The impact of economic integration on FDI and exports: A gravity approach. Centre for European Policy Studies, Working Document, br. 156.

30.Dunning, J. H., 1993. International enterprises and the global economy. Workingham: AddisonWesley.

3I. Dunning, J. H., 1997. The European Internal market programme and inbound foreign direct investment. Journal of Common Market Studies, 35(2), str. I89-223. doi: http://dx.doi.org/IO.IIII/I468-5965.00048

32. Dunning, J. H., Narula, R., 1997. The investment development path revisited: Some emerging issues. u: Dunning, J. H., Narula, R., urednici. Foreign direct investment and governments. London, New York: Routledge, I-4I.

33. Eaton, J. and Tamura, A., I996. Japanese and U.S. exports and investment as conduits of growth. National Bureau of Economic Research, Working Paper, br. 5457.

34. EBRD, 20IO. Transition Report 2009: Transition in crisis. London: EBRD.

35. EUROSTAT - Statistical Office of the European Union. http://epp.eurostat.ec.europa.eu [Pristup: 20. 08. 2OII.].

36. Fidrmuc, J. and Fidrmuc, J., 2003. "Disintegration and Trade". Review of International Economics, II(5), str. 8II-829. doi: http:/ /dx.doi.org/IO.IO46/j.I467-9396.2003.004I9.X

37. Frenkel, M., Funke, K. and Stadtmann, G., 2004. A panel analysis of bilateral FDI flows to emerging economies. Economic Systems, 28(3), str. 28I-300. doi: http://dx.doi.org/IO.IOI6/j.ecosys.2004.01.005

38. Garibaldi, P. [et al.], 200I. What moves capital to transition economies?. International Monetary Fund, Staff Papers, 48, IO9-I45.

39. Girma, S., Greenaway, D. and Wakelin, K., 2002. Does antidumping stimulate FDI? Evidence from Japanese Firms in the UK. Weltwirtschaftliches Archiv, I38(3), str. 4I4-436. doi: http://dx.doi.org/IO.IOO7/BFO2707947

40. Google Earth. http://earth.google.com [Pristup: 04. 08. 20II.].

4I. Graham, E. G., 1996. "On the relationship among foreign direct investment and international trade in the manufacturing sector: Empirical results for the United States and Japan”. World Trade Organization, Staff Working Paper, br. RD-96-0o8.

42. Grosse, R. and Trevino, L. J., 2005. New institutional economics and FDI location in Central and Eastern Europe. Management International Review, 45(2), str. I23-I45.

43. Hejazi, W. and Safarian, A. E., 200I. The complementarity between U.S. foreign direct investment stock and trade. Atlantic Economic Journal, 29 (4), 420-437. doi: http://dx.doi.org/IO.IOO7/BFo229933I

44.Helpman, E. and Krugman, P. R., 1986. Market Structure and Foreign Trade: Increasing Returns, Imperfect Competition and the International Economy. Cambridge: MIT Press.

45. Helpman, E., I984. A simple theory of international trade with multinational corporations. Journal of Political Economy, 92(3), str. 45I-47I. doi: http://dx.doi.org/IO.Io86/26I236 
46.Helpman, E., 2006. Trade, FDI, and the organization of firms. Journal of Economic Literature, 44(3), str. 589-630. doi: http://dx.doi.org/IO.I257/jel.44.3.589

47. Hosseini, H., 2005. An economic theory of FDI: A behavioural economics and historical approach. Journal of Socio-Economics, 34(4), str. 528-54I. doi: http://dx.doi.org/IO.IOI6/j.socec.2005.07.00I

48.IMF, 2OII. International financial statistics yearbook 2OII, New York: IMF.

49. Kim, Y.-H., 2007. Impacts of regional economic integration on industrial relocation through FDI in East Asia. Journal of Policy Modeling, 29(I), str. I65-I80. doi: http://dx.doi.org/IO.IOI6/j.jpolmod.2006.04.008

50.Kreinin, M. E. and Plummer, M. G., 2008. Effects of regional integration of FDI: An empirical approach. Journal of Asian Economics, 19(5-6), str. 447-454. doi: http://dx.doi.org/Io.IoI6/j.asieco.2008.09.005

5I. Lefilleur, J and Maurel, M., 20IO. Inter- and intra-industry linkages as determinant of FDI in Central and Eastern Europe. Economic Systems, 34(3), str. 309-330. doi: http://dx.doi.org/Io.IoI6/j.ecosys.2009.12.002

52. Levi Yeyati, E., Panizza, U. and Stein, E., 2007. The cyclical nature of North-South FDI flows. Journal of International Money and Finance, 26(I), str. IO4-I30. doi: http://dx.doi.org/Io.Ior6/j.jimonfin.2006.IO.012

53. Lin, A.-I., 1995. Trade Effects of Foreign Direct Investment: Evidence from Taiwan with Four ASEAN Countries. Weltwirtschaftliches Archiv, I3I(4), str. 737-747. doi: http://dx.doi.org/IO.IOO7/BFO2707939

54.Linnemann, H., 1966. An econometric study of international trade flows. Amsterdam: NorthHolland.

55. Lipsey, R. E., 2002. Home and host country effects of FDI. National Bureau of Economic Research, Working Paper, br. 9293.

56. MacDermott, R., 2007. Regional trade agreement and foreign direct investment”. North American Journal of Economics and Finance, I8(I), str. IO7-II6. doi: http://dx.doi.org/IO.IoI6/j.najef.2006.09.004

57. Markusen, J. R. and Maskus, K. E., 1999. Multinational firms: Reconciling Theory and Evidence. National Bureau of Economic Research, Working Paper, br. 7163.

58. Markusen, J. R. and Maskus, K. E., 2002. Discriminating among alternative theories of the multinational enterprise. Review of International Economics, IO(4), str. 694-707. doi: http://dx.doi.org/IO.IIII/I467-9396.00359

59. Markusen, J. R. and Venables, A. J., I998. Multinational firms and the new trade theory. Journal of International Economics, 46(2), str. 183-203. doi: http://dx.doi.org/IO.IOI6/Soo22-1996(97)000524

6o. Markusen, J. R., 2002. Multinational firms and the theory of international trade. Cambridge: MIT Press.

6I. Medvedev, D., 20II. Beyond trade: the impact of preferential trade agreements on FDI flows. World Development, 4O(I), str. 49-6I. doi: http://dx.doi.org/Io.IoI6/j.worlddev.2OII.04.036

62. MFAEI, 2003. Croatia on the road to the European Union. Zagreb: Ministry of foreign affairs and European integration of the Republic of Croatia.

63. Nilsson, L., 2000. Trade integration and the EU economic membership criteria. European Journal of Political Economy, I6(4), str. 807-827. doi: http://dx.doi.org/Io.IoI6/SoI76-268o(99)0oo6o-9

64.Petroulas, P., 2007. The effect of the euro on foreign direct investment. European Economic Review, 5I(6), str. I468-I49I. doi: http://dx.doi.org/IO.IOI6/j.euroecorev.2006.IO.005

65. Pontes, J. P., 2007. A non-monotonic relationship between FDI and trade. Economic Letters, 95(3), str. 369-373. doi: http://dx.doi.org/Io.IoI6/j.econlet.2006.II.009

66. Ramirez, M. D., 2006. Economic and institutional determinants of foreign direct investment in Chile: A time-series analysis, I96o-200I. Contemporary Economic Policy, 24(3), str. 459-47I. doi: http://dx.doi.org/Io.Io93/cep/byjo27

67. Te Velde, D. W., 200I. Foreign direct investment and factor prices in U.S. manufacturing. Weltwirtschaftliches Archiv, 137(4), str. 622-643. doi: http://dx.doi.org/I0.I007/BFo2707426

68.UNCTAD, 2OII. World Investment Report 20II: Non-equity modes of international production and development. New York and Geneva: United Nations Conference on Trade and Development.

69.UNCTAD, 2012. Global Investment Trends Monitor: Global FDI Outflows Continued to Rise in $201 \mathrm{II}$ Despite Economic Uncertainties; However Prospects Remain Guarded. br. 9, I2. 04. 2012.

70.UNCTAD, 20I2. World Investment Prospects Survey 20IO-20I2. New York and Geneva: United Nations Conference on Trade and Development.

7I. UNCTAD. FDI statistical database. Dostupno na: http:/ / www.unctad.org [Pristup: I8. o6. 20II.]. 
72. Vukšić, G., 2005. Impact of foreign direct investment on Croatian manufacturing exports. Financial Theory and Practice, 29(2), str. I47-I75.

73. Wang, Z. Q. and Swain, N., J., I995. The determinants of foreign direct investment in transforming economies: Empirical evidence from Hungary and China. Weltwirtschaftliches Archiv, I3I(2), str. 359-382. doi: http://dx.doi.org/IO.IOO7/BFO2707440

74. WIIW, 2009. Handbook on statistics: Countries in transition 2009. Vienna: Wiener Institut für internationale Wirtschaftsvergleiche.

75. WIIW, 20I2. WIIW Database on Foreign Direct Investment in Central, East and Southeast Europe 2012: Short-lived Recovery (izradio: Hunya, G.), svibanj 20I2., Vienna: Wiener Institut für internationale Wirtschaftsvergleiche.

76. Yu, C.-F., Chang, T.-C. and Fan, C.-P., 2007. FDI timing: Entry cost subsidy versus tax rate reduction". Economic Modeling, 24(2), str. 262-27I. doi: http://dx.doi.org/IO.IOI6/j.econmod.2006.07.004 